\title{
Transient Electrochemical Heat Transfer Modeling and Experimental Validation of a Large Sized $\mathrm{LiFePO}_{4} /$ Graphite Battery
}

\author{
S. Panchal*1, I. Dincer ${ }^{1}$, M. Agelin-Chaab ${ }^{1}$, R. Fraser ${ }^{2}$, and M. Fowler ${ }^{3}$ \\ ${ }^{1}$ Department of Automotive, Mechanical \& Manufacturing Engineering, Faculty of Engineering \& Applied Science, \\ University of Ontario Institute of Technology, 2000 Simcoe Street North, Oshawa, Ontario, Canada, L1H 7K4 \\ ${ }^{2}$ Mechanical and Mechatronic Engineering Department, University of Waterloo, 200 University Avenue West, \\ Waterloo, Ontario, Canada, N2L 3G1 \\ ${ }^{3}$ Chemical Engineering Departments, University of Waterloo, 200 University Avenue West, Waterloo, Ontario, \\ Canada, N2L 3G1 \\ *Corresponding Author's Telephone: +1-519-722-4420 \\ *Corresponding Author's Email: satyam.panchal@uoit.ca, satyam.panchal@uwaterloo.ca
}

\begin{abstract}
Measurement and modeling of thermal performance in lithium-ion battery cell is crucial which directly affects the safety. Even though the operation of a lithium-ion battery cell is transient phenomena in most cases, most available thermal models for lithium-ion battery cell predicts only steady-state temperature fields. This paper presents a mathematical model to predict the transient temperature distributions of a large sized 20Ah-LiFePO 4 prismatic battery at different C-rates. For this, the Lithium-ion battery was placed in a vertical position on a stand inside the lab with an ambient air cooling and the battery is discharged under constant current rate of $1 \mathrm{C}, 2 \mathrm{C}, 3 \mathrm{C}$, and $4 \mathrm{C}$ in order to provide quantitative data regarding thermal behaviour of lithium-ion batteries. Additionally, IR images are taken for the same battery cell during discharging. Model predictions are in good agreement with experimental data and also with an IR imaging for temperature profiles. The present results show that increased C-rates results in increased temperature on the principle surface of the battery.
\end{abstract}

Keywords: Heat transfer; thermal analysis; Lithium-ion battery; electrochemical model; ANSYS.

\section{Introduction}

The automotive industry has been forced to move towards sustainable vehicles such as electric vehicles (EVs), hybrid electric vehicles (HEVs), plug-in hybrid electric vehicles (PHEVs), and fuel cell vehicles (FCVs) to alleviate the environmental issues. These days, lithium-ion batteries are gaining widespread acceptance in the development of EVs, HEVs, and PHEVs [1]. Their extensive usage is due to: 1) high specific energy and power densities [2,3]; 2) high nominal voltage and low self-discharge rate [4]; and 3) long cycle-life and no memory effect [5]. To extend the life of battery, precautions must be taken during discharging and charging since, for example exceeding voltage, current or power limits may result in battery cell damage. The possibility of thermal runaways also occurs if care is not properly taken $[6,7]$. Moreover, 
lithium-ion polymer batteries must be carefully monitored and managed (electrically and thermally) to avoid safety (inflammability) and performance related issues $[8,9,10,11,12]$.

There are various papers in the open literature available for battery thermal modeling, using different approaches such as artificial neural network [13, 14, 15], finite element model (FEM) [16, 17] or lumped parameter model (LPM) [18], linear parameter varying (LPV) model [19], or partial differential equation (PDE) model [20], CFD models [21, 22, 23, 24, 25, 26]. Battery modeling based on electrochemical equations provides a deep understanding of the physical and chemical process inside the battery which makes it useful when designing a cell, but high computational time makes these models improper for applications with high dynamics. The first electrochemical modeling approach to porous electrodes with battery applications was presented by Newman and Tiedemann in 1975 [27]. In the porous electrode theory, the electrode is treated as a superposition between the electrolytic solution and solid matrix. The matrix itself is modeled as microscopic spherical particles where lithium ions diffuse and react on the surface of the sphere. This approach was expanded to include two composite models and a separator by Fuller et al. in 1994 [28]. This model was later adapted for Ni-MH batteries [29], and then lithium-ion batteries [30].

Li et al. [22] studied physics-based CFD simulation of a lithium-ion battery with the drive cycle of FUDS and used Newman's pseudo-2D (P2D) porous electrode model for a large sized lithium-ion battery. They also addressed two major problems to implement such models in the electrochemical-thermal coupled battery simulation. The first was how to use such an electrode-scale model in a large scale simulation and the second was how to make the physics-based model cost-efficient in a CFD simulation. In their study, to address the first technical issue, they used the multi-scale multi-dimensional approach (MSMD), and to address the second issue, they used a linear approximation.

Majdabadi et al. [31] built up a physics-based model to anticipate the thermal and electrical performance of a $\mathrm{LiFePO}_{4}$ battery under different operating conditions. They simplified Newman's full-order porouselectrode model at the electrode-level by using polynomial approximations for electrolyte variables, while at the molecule level, a multi-particle model featuring variable solid-state diffusivity was utilized. The computational time was reduced by almost one order of magnitude when contrasted with the full-order model without sacrificing the preciseness of the results. Their model was general and can be utilized to expedite the simulation of any composite electrode with active-material particles of non-uniform properties (e.g., contact resistance, size).

Mastali et al. [32] similarly developed an electrochemical-thermal model of a commercial Graphite/LiFePO 4 prismatic cell (20 Ah capacity) using FORTRAN code. They conducted the validation against the experimental data for charge/discharge rates varying from $1 \mathrm{C}$ to $5 \mathrm{C}$. Physics-based one- 
dimensional electrochemical models were coupled with charge conservation and heat diffusion equations to describe the electrochemical and thermal variable distributions throughout the battery domain. All the electrochemical properties of the graphite and LiFePO4 electrodes were obtained from half-cell simulations performed on the same electrode materials.

$\mathrm{Xu}$ et al. [33] built up a pseudo 3D electro-chemical-thermal model for a large sized prismatic $\mathrm{LiFePO}_{4}$ battery during the discharge process by coupling the mass, charge, and energy conservations, and the cell electrochemical kinetics. They studied both the electrochemical and thermal performance of the battery. Their model treated the battery with the current collecting tabs as 3D and the local cell units as $1 \mathrm{D}$. They also introduced a consistency index describing the SOC distributions among $1 \mathrm{D}$ cell units. This index was utilized to explore the effects of the tab arrangement on the consistency of the battery cell. They similarly found that the location of the current collecting tabs (of the negative and positive) on the prismatic battery had a great impact on the distributions of its potential and local reaction rates, which therefore affect the rate of heat generation, and subsequently the distribution of temperature inside the battery.

Additionally, Yang et al. [34] performed an examination of the uneven discharging and aging as a result of the difference in temperature among the parallel-connected battery cells. They built a thermalelectrochemical model for the parallel-connected battery pack and found that, at a higher temperature, the cell encounters a bigger current in the early discharging process before around 75\% of DOD for the parallelconnected cells. Their simulations also demonstrated that the temperature difference between the parallelconnected battery cells incredibly aggravates the irregularity discharge between the cells, which accelerated the losses of the battery pack capacity. For the pack with parallel-connected batteries, the rate of capacity loss approximately increased linearly as the difference in temperature between each cell increased.

Huo et al. [35] also presented a 3D model of the thermal performance of a lithium-ion battery. The effect of the discharge conditions on the thermal behavior was determined by utilizing the FEM. They analyzed the dynamic thermal behavior by utilizing various drive cycles and concluded that, natural convection was adequate to keep the temperature at $25^{\circ} \mathrm{C}$.

Lastly, Lai et al. [36] also built up a pseudo two-dimension (P2D) electrochemical model combined with a 3D heat transfer model. Their numerical model solved conservation of energy throughout the battery by considering the sources of heat generation; for example, electrochemical reactions, active polarization, and ohmic losses. Their outcomes showed an identical behavior of the temperature profile with thermal imaging and voltage distribution. They additionally found that the heat generation of the current collectors and separator was generally lower in magnitude, demonstrating little effect on temperature changes. The 
reversible heat variations on the positive side affected the aggregate reversible heat, while the negative irreversible heat had a predominant position in the total irreversible heat.

Infra-red (IR) imaging technique is also an excellent tool for the temperature measurement on the surface of an object. It provides several advantages over other types of temperature sensors. It is basically noncontact and also gives very helpful details of the surface being studied [37]. Some examples are:

Streza et al. [38] used an IR camera (FLIR 7200 series) to capture the thermal images of lead-acid batteries to investigate the distribution of current in the electrodes. They designed a special cell $(14 \mathrm{~cm} \mathrm{x} 14 \mathrm{~cm})$ with electrodes in direct contact with an air. The information was extracted during the discharge process by analysis of the heat dissipation in the electrode. The effect of the current in the metallic grid can be deconvoluted by the total heat generated in the electrode by numerical processing of the temperature profile on the surface of an electrode. Their proposed method had the potential to become an important tool in optimising electrode geometry because of its simplicity and effectiveness.

Bazinski et al. [39] also utilized a combined method of thermography technique along with a closed-form lumped capacitance model (LCM) in order to predict the heat generation inside the 14.5 Ah lithium-ion phosphate pouch cell. They used a FLIR A320 IR thermal camera to capture the images at high discharge rates of $1 \mathrm{C}, 2 \mathrm{C}, 3 \mathrm{C}$, and $5 \mathrm{C}$, as well as at a low discharge rate of $\mathrm{C} / 4$. The authors found that, at lower $\mathrm{C}$ rate, the temperature is uniform while at higher C-rates localized hot spots developed in the cell and the spatial temperature were not uniform.

\section{Experimental Set-up and Procedure}

The battery test set-up is shown in Figure 1 (a). A 20 Ah prismatic lithium-ion pouch type battery cell was used for the test measurements and subsequent model validation. Table 1 tabulates the cell specifications. For an ambient air cooling method, the lithium-ion battery was placed in a vertical position on a stand inside the lab where the temperature was $22^{\circ} \mathrm{C}$. The test bench consists five components: load box, charging unit, LabVIEW, National Instrument (NI) temperature measurement device, Computer 1 and Computer 2. Four different discharge rates (constant current) were selected: $1 \mathrm{C}, 2 \mathrm{C}, 3 \mathrm{C}$, and $4 \mathrm{C}$. The charge rate (constant current-constant voltage) was 1C. The experimental plan is shown in Table 2. XBL 50-150-800 Dynaload load box with a maximum capacity of $800 \mathrm{~W}$ was used to discharge the battery cell. TDK-Lambda power supply with a capacity of maximum $20 \mathrm{~V}$ and 40 A was used to charge the battery cell. Heavy duty copper cables were used to connect battery cell with load box and charging unit through a $100 \mathrm{~A}$ fuse. T-type thermocouple used to measure the temperature was connected to NI temperature measurement device, 
which is further connected to the computer. LabVIEW 8.2 software was used to control and operate the NI temperature measurement device at the computer.

The experimental set-up during IR imaging is shown in Figure 1 (b). Flir Therma CAM S60 camera was used in order to capture the IR images of the battery during discharging. This thermal camera has a $320 \mathrm{x}$ 240 detector, standard temperature range $0-500^{\circ} \mathrm{C}$ and an accuracy of $2 \%$ (typically $2^{\circ} \mathrm{C}$ ). The sensor is able to detect temperature variances as small as $0.06^{\circ} \mathrm{C}$. The camera was positioned on a tripod outside the enclosing box and pointed such that the detector viewed only the battery. For IR imaging experiments, first, the charging was performed on the battery until the battery reached a fully charged state. Second, when the battery was fully charged, the camera was oriented in a level position and pointed such that it viewed only the surface of the battery. Settings in the camera were prepared to record images at 20 second intervals once underway. Third, discharge current rate was modified in the battery cycling stand computer, and the internal clocks on the camera and computer were synchronized. The battery discharge and camera recording were then activated simultaneously.

\section{Model Development}

This model is basically a Newman's pseudo two dimensional (P2D) for a large sized prismatic lithium-ion battery. In this model, the physics-based two-dimensional electrochemical models are combined with the charge conservation and heat diffusion equations throughout the battery domain in order to calculate the temperature distributions. The governing equations and boundary conditions, along with the parameters used for the model development and material properties, are presented. The utilized physics-based twodimensional models accurately predict the behavior of the negative and positive electrodes considering the material phase-change inside the active electrode particles and the particle-size distribution observed in scanning electron microscope (SEM) images of electrodes. This approach provides the opportunity of precisely studying even the particle-level phenomena effects on the prismatic cell electrochemical-thermal behaviors. The developed model for the 20 Ah prismatic battery cell is compared against the experimental data for the temperature distribution on the surface of the prismatic cell during discharge at $2 \mathrm{C}, 3 \mathrm{C}$, and $4 \mathrm{C}$.

\subsection{Geometry and Meshing}

The Newman P2D model, initially presented by Doyle at el. [40, 28] and utilized by different researchers $[41,42]$, separates the battery into the particle and electrode domains. In the particle domain, the conservation of lithium is solved. The particles are usually considered to be spherical and Fick's law governs the particle lithium diffusion. In the electrode domain, the conservation of charge in the solid-phase and electrolyte, as well as the conservation of mass in the electrolyte, is solved. This model, based on the 
principles of transport phenomena, electrochemistry, and thermodynamics, is introduced by couple nonlinear partial differential equations (PDEs) in $x, r$, and $t$ that can take from a second to a minute for simulation. This model expands on the ohmic porous-electrode model by including diffusion in electrolyte and solid phases, as well as Butler-Volmer kinetics. Doyle created a P2D model based on a concentrated solution theory to describe the internal behavior of a lithium-ion sandwich consisting of positive $(+)$ and negative (-) electrodes, a separator and current collector. This physics-based model is by far the most used by battery researchers and solves for the electrolyte concentration, electrolyte potential, solid state potential, and solid state concentration within the porous electrodes and electrolyte concentration, and electrolyte potential within the separator.

Figure 2 is a schematic diagram of lithium-ion battery cell configuration for the pseudo-two dimensional multi-particle model [33]. During the discharge process, lithium diffuses to the surface of the negativeelectrode particles and undergoes an electrochemical reaction. This reaction releases an electron and transfers lithium to the electrolyte phase. The lithium-ions diffuse and conduct through the electrolyte solution to the positive electrode, where a similar reaction transfers lithium to the positive solid phase. Lithium is stored inside the positive electrode particles until the cell is later recharged. The lithium-ion transport phenomena in the porous electrode and active particle material can be described by the charge and mass conservation laws. Charge conservation governs the electrolyte phase potential and the solid phase potential, $\emptyset_{e}$ and $\emptyset_{s}$, while mass conservation governs the electrolyte phase concentration and the solid phase concentration, $C_{e}$ and $C_{s}$.

The geometry of a large sized $20 \mathrm{Ah}-\mathrm{LiFePO}_{4}$ battery used to verify the model results is shown in Figure 3 (a) and the actual cell is presented in Figure 3 (b). The current collecting tabs of the prismatic battery cell are also considered and the dimensions of the battery cell along with tabs also appears in Figure 3 (a). The studied prismatic cell includes a number of individual cells connected in parallel. Each cell contains a negative electrode, a separator, and a positive electrode, surrounded on either side by the current collectors. In the prismatic cell studied in this paper, the negative and positive electrodes active materials are made from graphite and $\mathrm{LiFePO}_{4}$, respectively. Copper is used as the negative current collector and aluminum as the positive current collector. This cell includes 48 individual cells, resulting in a $20 \mathrm{Ah}$ nominal capacity. In order to decrease the material demand and reduce the electrical losses, current collectors are covered by electrode materials on both sides. Therefore, the number of aluminum current collectors for 48 cells is 24 , while there are 24 copper collectors since copper collectors are on each end of the stack. All the layers are then enclosed in a separator sheet and a casing covers all. 


\subsection{Governing Equations and Boundary Conditions}

In this section, all governing equations for charge conservation in solid phase, charge conservation in electrolyte phase, lithium conservation in solid phase, lithium conservation in electrolyte phase, and the Butler-Volmer equation are described with their boundary conditions.

\subsubsection{Charge conservation in solid phase}

The charge conservation equation in the solid electrode material is governed by Ohm's law [22, 43]:

$$
\nabla\left(\sigma^{e f f} \nabla \emptyset_{s}\right)-j^{L i}=0
$$

in other words,

$$
\begin{gathered}
\frac{\partial}{\partial x}\left(\sigma^{e f f} \frac{\partial \emptyset_{s}}{\partial x}\right)=j^{L i} \\
-\sigma_{-}{ }^{e f f}\left(\frac{\partial \emptyset_{s}}{\partial x}\right)_{x=0}=\frac{I}{A} \quad \text { and } \quad+\sigma_{+}^{e f f}\left(\frac{\partial \emptyset_{s}}{\partial x}\right)_{x=L}=\frac{I}{A} \\
\left(\frac{\partial \emptyset_{s}}{\partial x}\right)_{x=l_{n}}=0 \quad \text { and } \quad\left(\frac{\partial \emptyset_{s}}{\partial x}\right)_{x=l_{n}+l_{s}}=0
\end{gathered}
$$

where $\sigma^{e f f}$ is the effective conductivity of the solid phase. $\sigma_{+}$and $\sigma_{-}$are effective electrical conductivity for the positive and negative electrodes. $\emptyset_{+}$and $\emptyset_{-}$are the phase potential positive and negative electrodes. $l_{n}$ is the length of the negative electrode, $l_{s}$ is the length of the separator, $l_{p}$ is the length of the positive electrode. $L=l_{n}+l_{s}+l_{p}$ is the overall length.

\subsubsection{Charge conservation in electrolyte phase}

The charge conservation in the electrolyte solution is expressed as [22, 43]:

$$
\nabla\left(k^{e f f} \nabla \emptyset_{e}\right)+\nabla\left(k_{D}^{e f f} \nabla \ln c_{e}\right)+j^{L i}=0
$$

in other words,

$$
\begin{gathered}
\frac{\partial}{\partial x}\left(k^{e f f} \frac{\partial \emptyset_{e}}{\partial x}\right)+\frac{\partial}{\partial x}\left(k_{D}^{e f f} \frac{\partial \ln c_{e}}{\partial x}\right)=-j^{L i} \\
\left(\frac{\partial \emptyset_{e}}{\partial x}\right)_{x=0}=0 \quad \text { and } \quad\left(\frac{\partial \emptyset_{e}}{\partial x}\right)_{x=L}=0
\end{gathered}
$$


where $k^{\text {eff }}$ is the effective diffusional conductivity called the Burggeman relation and is given by $k^{\text {eff }}=$ $k \epsilon_{e}{ }^{\beta}$, where $\beta$ is the Burggeman porosity exponent. $k_{D}{ }^{e f f}$ is the effective ionic conductivity, given by:

$$
{k_{D}}^{\text {eff }}=\frac{2 R T k^{e f f}}{F}\left(t_{+}{ }^{0}-1\right)\left(1+\frac{d \ln f_{ \pm}}{d \ln C_{e}}\right)
$$

where $f_{ \pm}$is the molecular activity coefficient of the electrolyte, also called the electrolyte activity coefficient. $\epsilon_{e}$ is the volume fraction of the electrolyte phase in the electrode, $R$ is the universal gas constant with a value of $8.3143 \mathrm{~kJ} / \mathrm{kg}$ mole. K. $F$ is the Faraday's constant and its value is 96485 Columb $/$ mole. $t_{+}{ }^{0}$ is the transfer number of lithium-ion. $C_{e}$ is the concentration of lithium in the electrolyte phase.

\subsubsection{Lithium conservation in solid phase}

The material balance for lithium-ions in an active solid material particle is governed by Fick's second law in spherical coordinate [22, 44]:

$$
\frac{\partial C_{s}}{\partial t}-\frac{D_{s}}{r^{2}} \frac{\partial}{\partial r}\left(r^{2} \frac{\partial C_{s}}{\partial r}\right)=0
$$

with boundary conditions'

$$
D_{S}\left(\frac{\partial C_{s}}{\partial r}\right)_{r=0}=0 \quad \text { and } \quad-D_{s}\left(\frac{\partial C_{s}}{\partial r}\right)_{r=R_{S}}=\frac{j^{L i}}{a_{S} F}
$$

where $C_{s}$ is the concentration of lithium in solid phase. $D_{S}$ is the mass diffusion coefficient of lithium-ion in the electrolyte, $r$ is the radial coordinate along the active material particle, $R_{S}$ is the radius of the solid active material particle, $j^{L i}$ is the transfer current resulting from Lithium insertion/de-insertion at the electrode/electrolyte interface, which consumes/generates the species $\mathrm{Li}^{+}$,

$$
j^{L i}=a_{s} i_{o}\left\{\begin{array}{c}
a_{s, a} i_{n, a} \\
0 \\
a_{s, c} i_{n, c}
\end{array}\right. \text { in the anode, separator and cathode }
$$

\subsubsection{Lithium conservation in electrolyte phase}

The lithium-ion balance in the liquid phase is described as follows [22]:

$$
\frac{\partial\left(\epsilon_{e} c_{e}\right) C_{s}}{\partial t}-\nabla\left(D_{e}^{e f f} \nabla c_{e}\right)-\frac{1-t_{+}^{0}}{F} j^{L i}+\frac{i_{e} \nabla t_{+}}{F}=0
$$


in other words,

$$
\begin{gathered}
\frac{\partial\left(\epsilon_{e} C_{e}\right) C_{s}}{\partial t}=\frac{\partial}{\partial x}\left(D_{e}^{e f f} \frac{\partial C_{e}}{\partial x}\right)+\frac{1-t_{+}^{0}}{F} j^{L i}+\frac{i_{e} \nabla t_{+}}{F} \\
\left(\frac{\partial C_{e}}{\partial x}\right)_{x=0}=0 \quad \text { and } \quad\left(\frac{\partial C_{e}}{\partial x}\right)_{x=L}=0
\end{gathered}
$$

where $\epsilon_{e}$ is the volume fraction/porosity of the electrolyte, $D_{e}{ }^{e f f}$ is the effective diffusion coefficient

(Burggeman relation, $D_{e}{ }^{\text {eff }}=D_{e} \epsilon_{e}{ }^{\beta}$ ), $t_{+}{ }^{0}$ is the transfer number of $\mathrm{Li}^{+}$with respect to the velocity of the solvent (a function of electrolyte concentration, if assuming constant, $\frac{i_{e} \nabla t_{+}}{F}=0$ ). Also, $\epsilon_{s}$ is the volume fraction of solid particle (active material) in the electrode. $\epsilon_{f}$ is the volume fraction of filler material in the electrode.

\subsubsection{Electrochemical Kinetics: Reaction Rate (Butler-Volmer Equation)}

The electrochemical reaction rate on the surface of electrode particles is usually governed by the ButlerVolmer equation $[33,35,45]$; i.e the Butler-Volmer equation is used to couple a charge-species governing equation and is given by:

$$
j^{L i}=a_{s} i_{o}\left\{\exp \left[\frac{\propto_{a} F}{R T} \eta\right]-\exp \left[\frac{\propto_{c} F}{R T} \eta\right]\right\}
$$

where the local surface over potential is given by [46]:

$$
\eta=\emptyset_{s}-\emptyset_{e}-U
$$

and the exchange current density is given by [43]:

$$
i_{0}=k_{m}\left(C_{e}\right)^{\alpha_{a}}\left(C_{s, \max }-C_{s, e}\right)^{\propto_{a}}\left(C_{s, e}\right)^{\alpha_{c}}
$$

where $a_{s}$ is the active surface area per electrode unit volume for electron transfer reactions $(1 / \mathrm{cm}), i_{0}$ is the exchange current density (a function of lithium concentrations in both electrolyte and solid active materials), $\propto_{a}$ is the transfer coefficient of the anode, $\mathrm{T}$ is the temperature $(\mathrm{K}), \eta$ is the over potential $(\mathrm{V})$, $\propto_{c}$ is the transfer coefficient of the cathode, $\mathrm{U}$ is thermodynamics OCV, $C_{s, \max }$ is the maximum concentration of lithium in solid phase and $C_{s, e}$ is the concentration of lithium at the surface of solid particles, and $\emptyset_{s}$ and $\emptyset_{e}$ are the phase potential for solid and electrolyte phase.

For coupling the model, temperature dependent physicochemical properties, such as diffusion coefficient $\left(D_{s}\right)$ and ionic conductivity of an electrolyte $(k)$ are needed and dependence can be generally described by Arrhenius Equation [43]: 


$$
\begin{aligned}
& D_{s}=D_{s, r e f} \exp \left[\frac{-E_{d}}{R\left(\frac{1}{T}-\frac{1}{T_{\text {ref }}}\right)}\right] \\
& k_{m}=k_{m, \text { ref }} \exp \left[\frac{-E_{r}}{R\left(\frac{1}{T}-\frac{1}{T_{\text {ref }}}\right)}\right]
\end{aligned}
$$

also diffusion coefficient in electrolyte phase, $D_{e}$, is given by:

$$
\begin{gathered}
D_{e}^{e f f}=D_{e} \epsilon_{e}{ }^{\beta} \\
a_{s}=3 \frac{\epsilon_{s}}{r_{s}}
\end{gathered}
$$

where $a_{s}$ is the solid/electrolyte interfacial area per unit volume, $D_{s}$ is the diffusion coefficient in solid phase, $D_{s, r e f}$ is the reference solid diffusion coefficient, $k_{m, r e f}$ is the reference reaction rate coefficient, $D_{e}$ is the diffusion coefficient in the electrolyte phase, $E_{d}$ is the activation energy that controls temperature sensitivity of $\mathrm{D}_{\mathrm{s}}, E_{r}$ is the activation energy that controls the temperature sensitivity of $k_{m}$, and $T_{r e f}$ is the reference temperature $=298 \mathrm{~K}$.

\subsubsection{Energy Equation}

The energy balance equation is given by [22]:

$$
\nabla^{2} T+\frac{\dot{q}}{k}=\frac{1}{\alpha} \frac{\partial T}{\partial t}
$$

in other words,

$$
\frac{\partial^{2} T}{\partial x^{2}}+\frac{\partial^{2} T}{\partial y^{2}}+\frac{\partial^{2} T}{\partial z^{2}}+\frac{\dot{q}}{k}=\frac{1}{\alpha} \frac{\partial T}{\partial t}
$$

The above equation is further modified to

$$
\dot{q}=\frac{\partial\left(\rho c_{p} T\right)}{\partial t}-\nabla(k \nabla T)
$$

also,

$$
\nabla\left(\sigma_{+} \nabla_{\emptyset_{+}}\right)=-j
$$




$$
\begin{gathered}
\nabla\left(\sigma_{-} \nabla_{\emptyset_{-}}\right)=+j \\
\dot{q}=\left(\sigma_{+} \nabla^{2} \phi_{+}\right)+\left(\sigma_{-} \nabla_{\emptyset_{-}}^{2}\right)+\dot{q}_{E C H}
\end{gathered}
$$

where $\dot{q}_{E C H}$ is the electro chemical heat and is given by [22]:

$$
\dot{q}_{E C H}=\frac{i_{p}\left(\emptyset_{+}-\emptyset_{-}\right)+\left(\sigma_{-} \nabla^{2} \emptyset_{-}\right)+\int_{0}^{L} j^{L i}\left(T_{r e f} \frac{\partial U}{\partial t}-U_{r e f}\right) d x}{L}
$$

also,

$$
\begin{gathered}
i_{p}=\int_{0}^{l_{p}} j^{L i} d x \\
j=-a i_{p}
\end{gathered}
$$

where $\dot{q}$ is the heat generation rate during battery operation which includes joule heating, electrochemical reaction heating and entropic heating, $\rho$ is the density, $c_{p}$ is the specific heat. The parameters used for the modeling are shown in Table 3. The material properties are also presented in Table 4. These properties are used in the simulation.

\section{Results and Discussion}

Figure 4 shows the validation of experimental and simulated temperature field results at $2 \mathrm{C}, 3 \mathrm{C}$, and $4 \mathrm{C}$ discharge rates. The operating condition for the battery under different $\mathrm{C}$-rates $(2 \mathrm{C}, 3 \mathrm{C}$, and $4 \mathrm{C})$ is at an initial temperature of $22^{\circ} \mathrm{C}$. As shown in Figure 4, the average surface temperature increases by $14^{\circ} \mathrm{C}, 24^{\circ} \mathrm{C}$, and $36^{\circ} \mathrm{C}$ above the ambient temperature for the discharge rates of $2 \mathrm{C}, 3 \mathrm{C}$, and $4 \mathrm{C}$, respectively. It can also be seen that the surface temperature increases faster at a higher discharge rate. The variation of temperature profile with discharge time may be due to the internal heat generation. The advantage of the MSMD numerical model is its relatively high calculation speed, which ranges in order of minutes, with relatively high accuracy results. The quality of the computational mesh has a higher influence on the actual computational time. The simulation can give more accurate results if the computational mesh is finer and better quality.

Figure 5 ( $a$ and $b$ ) shows a comparison of the temperature contour of a battery at 4C discharge rate with IR image and simulation by the numerical model, as created with ANSYS Fluent software. It can be seen that, with simulation, the temperature at the end of the discharge rate is $69^{\circ} \mathrm{C}$ while with the IR image the 
temperature is $70^{\circ} \mathrm{C}$, which is very close. It was also noted that the highest temperature distribution was observed near the tabs (positive and negative electrode) as compared to the middle and the end on the principle surface of the battery along the height of the battery. The lowest spread in temperature is observed at the end on the surface of the battery along the height of the battery.

Figure 6 shows a series of IR images during 4C discharge. In all images the brightest white part is the area where the highest temperature distribution was observed and subsequently the heat generation was also higher. This series of images are purposefully introduced in this paper to see the surface temperature contours of battery between beginnings of the discharge to the end of the discharge. It was also found that after 540s the battery surface temperature increased faster and it became highest at 900s. After that the charging cycle started and the battery surface temperature decreased and it became the lowest at an around 1740s. Here, in this experiments, the charging was done at constant current-constant voltage (CC-CV) and discharging was done at constant current (CC). There was no resting period during discharging and charging.

\section{Conclusions}

This paper has presented a comparative study of the temperature distributions on a large sized 20Ah$\mathrm{LiFePO}_{4}$ prismatic battery cell using both experimentally and theoretically (through simulation methods by using electrochemical thermal approach) at 2C, 3C, and 4C discharge rates. Some closing remarks are then stated as follows: (i) the temperature distributions on the surface of the battery increase as the C-rates increase; (ii) the thermocouple sensors closest to the electrodes provide higher temperatures than the centerline-thermocouple sensors; (iii) the tab temperatures are always higher as compared to the surface temperatures; and (iv) the positive current collector temperature is always higher than the negative current collector for all the discharge rates. In addition, an experimental study was conducted using an IR camera to capture IR images at various discharge rates, and temperature non-uniformity was visually observed. The temperature non-uniformity was an indication of the non-uniformity in the heat generation on a surface of the battery and as such it was concluded that the area of highest temperature and non-uniformity is the location where the heat generation is highest. These results can provide physical insights for the design and thermal optimization of batteries.

\section{Nomenclature}

$a_{s} \quad: \quad$ solid/electrolyte interfacial area per unit volume or active surface area per electrode unit volume for electron transfer reactions $[1 / \mathrm{cm}]$

A $\quad$ area $\left[\mathrm{m}^{2}\right]$ 


\begin{tabular}{|c|c|c|}
\hline$c_{p}$ & : & specific heat capacity $\left[\mathrm{J} / \mathrm{kg}^{\circ} \mathrm{C}\right]$ \\
\hline$C_{p, p}$ & : & specific heat for positive tab $[\mathrm{J} / \mathrm{kg}-\mathrm{K}]$ \\
\hline$C_{p, n}$ & : & specific heat for negative tab $[\mathrm{J} / \mathrm{kg}-\mathrm{K}]$ \\
\hline$C_{p, a}$ & : & specific heat for active zone $[\mathrm{J} / \mathrm{kg}-\mathrm{K}]$ \\
\hline$C_{e}$ & : & concentration of lithium in electrolyte phase $\left[\mathrm{mol} / \mathrm{m}^{3}\right]$ \\
\hline$C_{s}$ & : & concentration of lithium in solid phase $\left[\mathrm{mol} / \mathrm{m}^{3}\right]$ \\
\hline$C_{s, p, \max }$ & : & maximum solid $\mathrm{Li}^{+}$Concentration for positive electrode $\left[\mathrm{mol} / \mathrm{m}^{3}\right]$ \\
\hline$C_{s, n, \max }$ & : & maximum solid $\mathrm{Li}^{+}$Concentration for negative electrode $\left[\mathrm{mol} / \mathrm{m}^{3}\right]$ \\
\hline$D_{s}$ & : & mass diffusion coefficient of lithium-ion in electrolyte \\
\hline$D_{s, p}$ & : & reference diffusivity for positive electrode $\left[\mathrm{m}^{2} / \mathrm{s}\right]$ \\
\hline$D_{s, n}$ & : & reference diffusivity for negative electrode $\left[\mathrm{m}^{2} / \mathrm{s}\right]$ \\
\hline$D_{s, r e f}$ & : & reference solid diffusion coefficient \\
\hline$D_{e}^{e f f}$ & : & effective diffusion coefficient \\
\hline$E_{d}$ & : & activation energy that controls temperature sensitivity of $D_{s}[\mathrm{~kJ} / \mathrm{mol}]$ \\
\hline $\mathrm{E}_{\mathrm{r}}$ & : & activation energy that controls temperature sensitivity of $k_{m}[\mathrm{~kJ} / \mathrm{mol}]$ \\
\hline$f_{ \pm}$ & : & $\begin{array}{l}\text { molecular activity coefficient of the electrolyte also called electrolyte activity } \\
\text { coefficient }\end{array}$ \\
\hline $\mathrm{F}$ & $:$ & Faraday`s constant [96485 Columb/mol] \\
\hline$i_{0}$ & $:$ & exchange current density $\left[\mathrm{A} / \mathrm{m}^{2}\right]$ \\
\hline$I$ & : & current $[\mathrm{A}]$ \\
\hline$j^{L i}$ & : & $\begin{array}{l}\text { transfer current resulting from lithium insertion/de-insertion at the } \\
\text { electrode/electrolyte interface }\left[\mathrm{A} / \mathrm{m}^{2}\right]\end{array}$ \\
\hline$k$ & : & ionic conductivity of electrolyte $[\mathrm{S} / \mathrm{m}]$ \\
\hline$k_{p}$ & : & reference rate constant for positive electrode $\left[\mathrm{mol} / \mathrm{m}^{2} \mathrm{~s} /\left(\mathrm{mol} / \mathrm{m}^{3}\right)^{1.5}\right]$ \\
\hline$k_{n}$ & : & reference rate constant for negative electrode $\left[\mathrm{mol} / \mathrm{m}^{2} \mathrm{~s} /\left(\mathrm{mol} / \mathrm{m}^{3}\right)^{1.5}\right]$ \\
\hline$k_{m, r e f}$ & : & reference reaction rate coefficient \\
\hline$k^{e f f}$ & : & effective diffusional conductivity $[\mathrm{S} / \mathrm{m}]$ \\
\hline$k_{D}^{e f f}$ & : & effective ionic conductivity $[\mathrm{S} / \mathrm{m}]$ \\
\hline$l_{n}$ & : & length of negative electrode $[\mu \mathrm{m}]$ \\
\hline$l_{s}$ & : & length of separator $[\mu \mathrm{m}]$ \\
\hline$l_{p}$ & : & length of the positive electrode $[\mu \mathrm{m}]$ \\
\hline$L$ & : & overall length $\left(L=l_{n}+l_{s}+l_{p}\right)$ in $[\mu \mathrm{m}]$ \\
\hline
\end{tabular}




$\begin{array}{lll}n & : & \text { number of electrons } \\ \dot{q} & : & \text { heat generation rate }[\mathrm{W}] \\ r & : & \text { radial coordinate along active material particle } \\ R & : & \text { resistance }[\Omega] \\ R & : & \text { universal gas constant }[8.3143 \mathrm{~kJ} / \mathrm{kg} \text { mole. } \mathrm{K}] \\ R_{S} & : & \text { radius of solid active material particle }[\mu \mathrm{m}] \\ R_{S, p} & : & \text { particle radius for positive electrode }[\mu \mathrm{m}] \\ R_{S, n} & : & \text { particle radius for negative electrode }[\mu \mathrm{m}] \\ T & : & \left.\text { temperature [ }{ }^{\circ} \mathrm{C} \text { or } \mathrm{K}\right] \\ t_{+}{ }^{0} & : & \text { transfer number of lithium-ion } \\ t & : & \text { time }[\mathrm{s}] \\ U & : & \text { electrode potential of the reaction or thermodynamic open circuit potential }[\mathrm{V}] \\ V & : & \text { cell voltage or cell potential [V] }\end{array}$

\section{Greek Symbols}

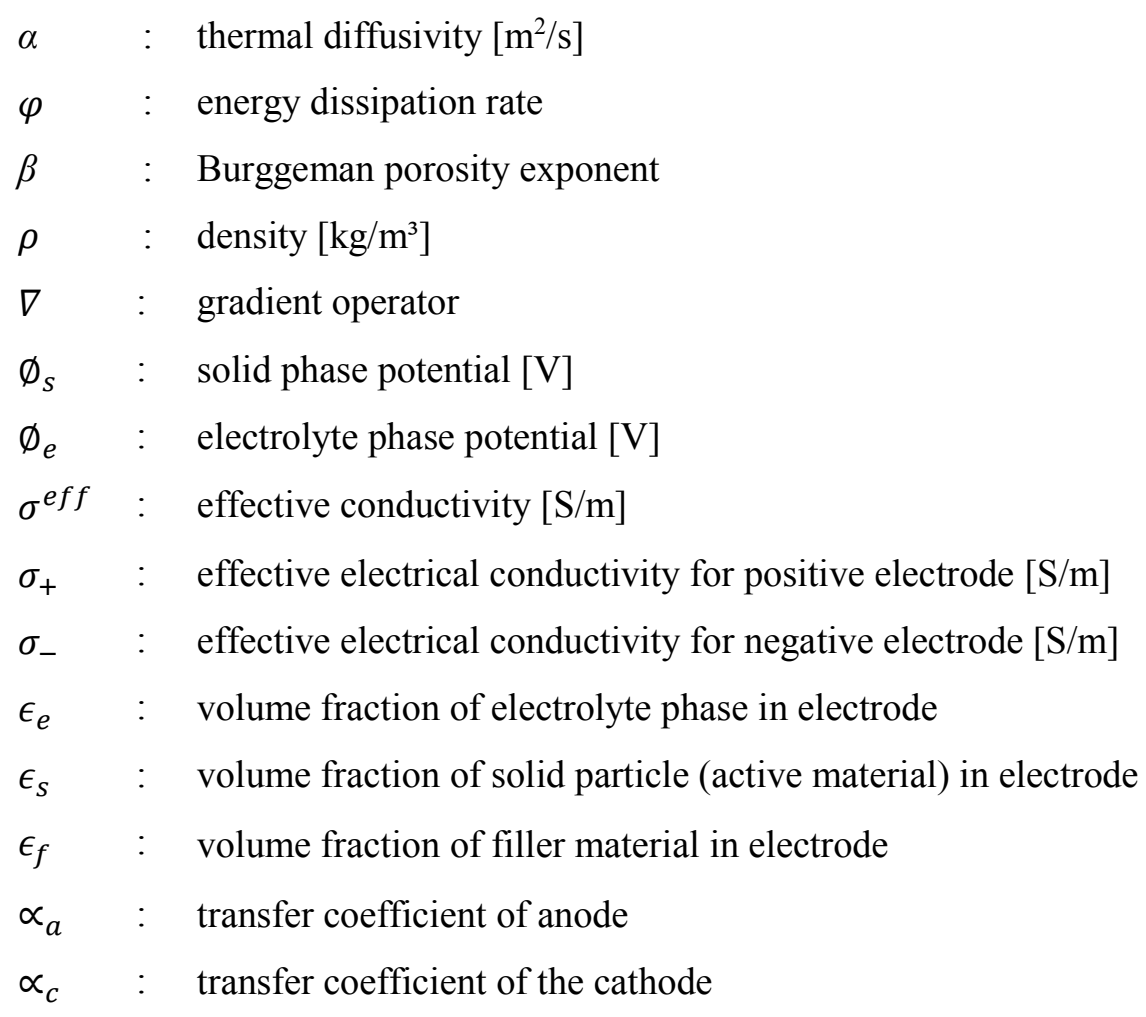

\section{Subscripts}

$\infty \quad$ : ambient 


$\begin{array}{lll}0 & : & \text { initial } \\ a & : & \text { anode } \\ c & : & \text { cathode } \\ e & : & \text { electrolyte } \\ f & : & \text { filler } \\ \exp & : & \text { experimental } \\ n & : & \text { negative electrode } \\ \text { oc } & : & \text { open circuit } \\ p & : & \text { positive electrode } \\ r e f & : & \text { reference } \\ s & : & \text { separator } \\ \text { sim } & : & \text { simulated } \\ \text { tot } & : & \text { total } \\ x, y, z & : & \text { Cartesian coordinate directions }\end{array}$

\section{Subscripts}

$\begin{array}{lll}\circ & : & \text { degree } \\ \text { Li } & : & \text { lithium } \\ \text { eff } & : & \text { effective } \\ \mathrm{ECH} & : & \text { Electrochemical heat }\end{array}$

\section{Acronyms}

ANSYS Inc. American Computer-aided engineering software developer

$\mathrm{BC}$ Boundary condition

$\mathrm{BEV}$ Battery electric vehicle

BTMS

Battery thermal management system

$\mathrm{C}$ Capacity

CFD

Computational fluid dynamics

DOD

Depth of discharge

ECT

Electrochemical thermal

ECM

Equivalent circuit-based modeling

EV Electric vehicle

FCV Fuel cell vehicle

FEA

Finite element analysis 


\begin{tabular}{ll} 
FEM & Finite element method \\
FUDS & Federal urban drive cycle \\
FORTRAN & derived from "Formula Translation" \\
HEV & Hybrid electric vehicle \\
HWFET & Highway fuel economy cycle \\
IR & Infra-red \\
Li-ion & Lithium ion \\
LiFePO 4 & Lithium iron phosphate \\
LCM & lumped capacitance model \\
LFP & Lithium phosphate \\
LPM & Lumped parameter model \\
LPV & Linear parameter varying \\
LabVIEW & Laboratory virtual instrument engineering workbench \\
MSMD & Multi scale multi domain \\
NiMH & Nickel metal hydride \\
OCV/OCP & Open circuit voltage/Open circuit potential \\
PC & Personal computer \\
P2D & Pseudo two dimensional \\
PDE & Partial differential equation \\
PHEV & Plug-in hybrid electric vehicle \\
SOC & State of charge \\
SEM & Scanning electron microscope \\
TC & Thermocouple \\
US06 & United states of America 06 drive cycle \\
UDDS & Urban dynamometer driving schedule \\
1D & ondimensional \\
2D & twonsional \\
\hline
\end{tabular}

\section{References}

[1] Q. Wang, Q. Sun, P. Ping, X. Zhao, J. Sun and Z. Lin, "Heat transfer in the dynamic cycling of lithium-titanate batteries," International Journal of Heat and Mass Transfer, no. 93, pp. 896-905, 2016 . 
[2] Z. Ling, F. Wang, X. Fang, X. Gao and Z. Zhang, "A hybrid thermal management system for lithium ion batteries combining phase change materials with forced-air cooling," Applied Energy, no. 148, pp. 403-409, 2015.

[3] H. Ge, J. Huang, J. Zhang and Z. Li, "Temperature-Adaptive Alternating Current Preheating of Lithium-Ion Batteries with Lithium Deposition Prevention," Journal of The Electrochemical Society, vol. 163, no. 2, pp. A290-A299, 2016.

[4] A. Ritchie and W. Howard, "Recent developments and likely advances in lithium-ion batteries," Journal of Power Sources, vol. 162, pp. 809-812, 2006.

[5] Y. Ye, L. H. Saw, Y. Shi and A. A. Tay, "Numerical analyses on optimizing a heat pipe thermal management system for lithium-ion batteries during fast charging," Applied Thermal Engineering, vol. 86, pp. 281-291, 2015.

[6] M. J. Isaacson, R. P. Hollandsworth, P. J. Giampaoli, F. A. Linkowsky, A. Salim and V. L. Teofilo, "Advanced Lithium-ion battery charger," Battery conference on Applications and Advances, pp. 193198, 2000.

[7] J. McDowall, P. Biensan and M. Broussely, "Industrial Lithium-ion battery safety-What are the tradeoffs?," in Telecommunications Energy Conference, 2007.

[8] Y. Xing, Q. Miao, K.-L. Tsui and M. Pecht, "Prognostics and health monitoring for lithium-ion battery," in IEEE International Conference on, 2011.

[9] X. Feng, M. Fang, X. He, M. Ouyang, L. Lu, H. Wang and M. Zhang, "Thermal runaway features of large format prismatic lithium ion battery using extended volume accelerating rate calorimetry," Journal of Power Sources, pp. 255 : 294-301, 2014.

[10] L. Lu, X. Han, J. Hua, M. Ouyang and J. Li, "A review on the key issues for lithium-ion battery management in electric vehicles," Journal of Power Sources, pp. 226:272-288, 2013.

[11] S. Panchal, I. Dincer, M. Agelin-Chaab, M. Fowler and R. Fraser, "Uneven temperature and voltage distributions due to rapid discharge rates and different boundary conditions for series-connected LiFePO 4 batteries," International Communications in Heat and Mass Transfer, vol. 81, pp. 210-217, 2017.

[12] S. Panchal, I. Dincer, M. Agelin-Chaab, R. Fraser and M. Fowler, "Experimental and simulated temperature variations in a LiFePO 4-20Ah battery during discharge process," Applied Energy, vol. 180, pp. 504-515, 2016.

[13] S. Panchal, I. Dincer, M. Agelin-Chaab, R. Fraser and M. Fowler, "Experimental and theoretical investigation of temperature distributions in a prismatic lithium-ion battery," International Journal of Thermal Sciences, no. 99, pp. 204-212, 2015. 
[14] S. Panchal, I. Dincer, M. Agelin-Chaab, R. Fraser and M. Fowler, "Thermal modeling and validation of temperature distributions in a prismatic lithium-ion battery at different discharge rates and varying boundary conditions," Applied Thermal Engineering, 2015.

[15] S. Panchal, I. Dincer, M. Agelin-Chaab, R. Fraser and M. Fowler, "Experimental and theoretical investigations of heat generation rates for a water cooled LiFePO4 battery," International Journal of Heat and Mass Transfer, vol. 101, pp. 1093-1102, 2016.

[16] A. Pruteanu, B. V. Florean, G. Maria Moraru and R. C. Ciobanu, "Development of a thermal simulation and testing model for a superior lithium-ion-polymer battery," in Optimization of Electrical and Electronic Equipment (OPTIM), IEEE, pages 947-952, 2012.

[17] J. Yi, U. S. Kim, C. B. Shin, T. Han and S. Park, "Three-dimensional thermal modeling of a lithiumion battery considering the combined effects of the electrical and thermal contact resistances between current collecting tab and lead wire," Journal of the Electrochemical Society, vol. 160, no. 3, pp. 437443, 2013.

[18] C. Alaoui, "Solid-State Thermal Management for Lithium-Ion EV Batteries," Vehicular Technology, IEEE Transactions on, vol. 62, no. 1, pp. 98-107, 2013.

[19] X. Hu, S. Asgari, S. Lin, S. Stanton and W. Lian, "A linear parameter-varying model for HEV/EV battery thermal modeling," in Energy Conversion Congress and Exposition (ECCE), IEEE, pages 1643-1649, 2012.

[20] A. Smyshlyaev, M. Krstic, N. Chaturvedi, J. Ahmed and A. Kojic, "PDE model for thermal dynamics of a large," in American Control Conference (ACC), IEEE, pages 959-964, 2011.

[21] A. Samba, N. Omar, H. Gualous, Y. Firouz, P. V. d. Bossche, J. V. Mierlo and T. I. Boubekeur, "Development of an Advanced Two-Dimensional Thermal Model for Large size Lithium-ion Pouch Cells," Electrochimica Acta, vol. 117, pp. 246-254, 2014.

[22] G. Li and S. Li, "Physics-Based CFD Simulation of Lithium-ion Battery under the FUDS Driving Cycle," ECS Transactions, vol. 64, no. 33, pp. 1-14, 2015.

[23] P. Vyroubal, T. Kazda, J. Maxa and J. Vondrák, "Analysis of Temperature Field in Lithium Ion Battery by discharging," ECS Transactions, vol. 70, no. 1, pp. 269-273, 2015.

[24] C. H. Wang, T. Lin, J. T. Huang and Z. H. Rao, "Temperature response of a high power lithium-ion battery subjected to high current discharge," Materials Research Innovations, vol. 19, pp. 156-160, 2015.

[25] L. W. Jin, P. S. Lee, X. X. Kong, Y. Fan and S. K. Chou, "Ultra-thin minichannel LCP for EV battery thermal management," Applied Energy, vol. 113, pp. 1786-1794, 2014. 
[26] K. Yeow, M. Thelliez, H. Teng and E. Tan, "Thermal Analysis of a Li-ion Battery System with Indirect Liquid Cooling Using Finite Element Analysis Approach," SAE International Journal, vol. 1, no. 1, pp. 65-78, 2012.

[27] J. Newman and W. Tiedemann, "Porous-Electrode Theory with Battery Application," AIChE, vol. 21, pp. 25-41, 1975.

[28] T. F. Fuller, M. Doyle and J. Newman, "Simulation and Optimization of the Dual Lithium Ion Insertation Cell," Journal of Electrochemical Society, vol. 141, pp. 1-10, 1994.

[29] C. Y. Wang, W. B. Gu and B. Y. Liaw, "Micro-Macroscopic Coupld Modeling of Batteries and Fuel Cells: Part II: Applications to Ni-Cd and Ni-MH Cells," Journal of Electrochemical Society, vol. 145, pp. 3418-3427, 1998.

[30] W. B. Gu and C. Y. Wang, "Thermal and Electrochemical Coupled Modeling of a Lithium-Ion Cell," Journal of Electrochemical Society, vol. 99, pp. 748-762, 2000.

[31] M. M. Majdabadi, S. Farhad, M. Farkhondeh, R. Fraser and M. Fowler, "Simplified electrochemical multi-particle model for LiFePO4 cathodes in lithium-ion batteries," Journal of Power Sources, vol. 275, no. 1, pp. 633-543, 2015.

[32] M. Mastali , E. Foreman, M. A, S. Farhad, R. Fraser and M. Fowler, "Electrochemical-Thermal Modeling of a Commercial Graphite/LiFePO4 Prismatic Cell," Journal of Power Sources, 2016.

[33] M. Xu, Z. Zhang, X. Wang, L. Jia and L. Yang, "A pseudo three-dimensional electrochemicalethermal model of a prismatic LiFePO4 battery during discharge process," Energy, vol. 80, pp. 303-317, 2015.

[34] N. Yang, X. Zhang, B. Shang and G. Li, "Unbalanced discharging and aging due to temperature differences among the cells in a lithium-ion battery pack with parallel combination," Journal of Power Sources, vol. 306, pp. 733-741, 2016.

[35] W. Huo, H. He and F. Sun, "Electrochemical-thermal modeling for a ternary lithium ion battery during discharging and driving cycle testing," RSC Advances, vol. 71, no. 5, pp. 57599-57607, 2015.

[36] Y. Lai, S. Du, L. Ai, A. Lihua, Y. Cheng, Y. Tang and J. Ming, "Insight into heat generation of lithium ion batteries based on the electrochemical-thermal model at high discharge rates," International Journal of Hydrogen Energy, vol. 40, pp. 3039-3049, 2015.

[37] C. Lin, S. Xu, Z. Li, B. Li, G. Chang and J. Liu, "Thermal analysis of large-capacity LiFePO4 power batteries for electric vehicles," Journal of Power Sources, vol. 294, pp. 633-642, 2015. 
[38] M. Streza, C. Nuţ, C. Tudoran, V. Bunea, A. Calborean and C. Morari, "Distribution of current in the electrodes of lead-acid batteries: a thermographic analysis approach," Journal of Physics D : Applied Physics, vol. 49, no. 5, pp. 55503-55510, 2016.

[39] S. J. Bazinski and X. Wang, "Predicting heat generation in a lithium-ion pouch cell through thermography and the lumped capacitance model," Journal of Power Sources, vol. 305, pp. 97-105, 2016.

[40] M. Doyle, T. F. Fuller and J. Newman, "Modeling of Galvanostatic Charge and Discharge of the Lithium/Polymer/Insertion Cell," Journal of The Electrochemical Society, vol. 140, no. 6, pp. 15261533, 1993.

[41] L. Cai and R. E. White, "Mathematical modeling of a lithium ion battery with thermal effects in COMSOL Inc. Multiphysics (MP) software," Journal of Power Sources, vol. 196, no. 14, pp. 59855989, 2011.

[42] M. Farkhondeh, M. Safari, M. Pritzker, M. Fowler, T. Han, J. Wang and C. Delacourt, "Full-Range Simulation of a Commercial LiFePO4 Electrode Accounting for Bulk and Surface Effects: A Comparative Analysis," Journal of The Electrochemical Society, vol. 161, no. 3, pp. A201-A212, 2014.

[43] A. Inc., "ANSYS Fluent Advanced Add-On Modules," ANSYS, Inc., November 2013. [Online]. Available: http://www.ansys.com. [Accessed November 2013].

[44] N. Yang, X. Zhang, G. Li and D. Hua, "Assessment of the forced air-cooling performance for cylindrical lithium-ion battery packs: A comparative analysis between aligned and staggered cell arrangements," Applied Thermal Engineering, vol. 80, pp. 55-65, 2015.

[45] A. Fotouhi, D. J. Auger, K. Propp, S. Longo and M. Wild, "A review on electric vehicle battery modelling : From Lithium-ion toward Lithium-Sulphur," Renewable and Sustainable Energy Reviews, vol. 56, pp. 1008-1021, 2016.

[46] Y. Huo, Z. Rao, X. Liu and J. Zhao, "Investigation of power battery thermal management by using mini-channel cold plate," Energy Conversion and Management, vol. 89, pp. 387-395, 2015.

[47] W. Fang, O. J. Kwon and C.-Y. Wang, "Electrochemical-thermal modeling of automotive Li-ion batteries and experimental validation using a three-electrode cell," International Journal of Energy Research, vol. 34, no. 2, pp. 107-115, 2009.

[48] M. M. Majdabadi Kohneh, E. Samadani, S. Farhad, R. Fraser and M. Fowler, "Three-Dimensional Electrochemical Analysis of a Graphite/LiFePO4 Li-Ion Cell to Improve Its Durability," SAE International, 2015. 
[49] W. Zhao, G. Luo and C.-Y. Wang, "Modeling Nail Penetration Process in Large-Format Li-Ion Cells," Journal of The Electrochemical Society, vol. 162, no. 1, pp. A207-A217, 2015.

[50] K. Smith and C.-Y. Wang, "Power and thermal characterization of a lithium-ion battery pack for hybrid-electric vehicles," Journal of Power Sources, vol. 160, no. 1, pp. 662-673, 2006.

\section{List of Table Captions}

Table 1: $\mathrm{LiFePO}_{4}-20 \mathrm{Ah}$ Lithium-ion pouch cell specifications

Table 2: Experimental plan

Table 3: Parameters used in the 2D Model

Table 4: Material Properties used in the simulation

\section{List of Figure Captions}

Figure 1: Experimental set-up during a) battery testing and b) IR imaging

Figure 2: Schematic diagram of lithium-ion battery cell configuration for the pseudo-two dimensional multi-particle model

Figure 3: Lithium-ion prismatic cell geometry for ECT model

Figure 4: Validation of experimental and simulated results at 2C, 3C, and 4C discharge rate

Figure 5: Comparison of temperature contour of battery at $4 \mathrm{C}$ discharge rate (simulated and real image)

Figure 6: Series of IR images during 4C discharge 


\section{Tables}

Table 1 : LiFePO$_{4}$ - 20Ah Lithium-ion pouch cell specifications

\begin{tabular}{ll}
\hline \multicolumn{1}{c}{ Specifications } & \multicolumn{1}{c}{ Value } \\
\hline Cathode Material & $\mathrm{LiFePO}_{4}$ \\
Anode Material & Graphite \\
Electrolyte & Carbonate based \\
Nominal Capacity & $20.0 \mathrm{Ah}$ \\
Nominal Voltage & $3.3 \mathrm{~V}$ \\
Dimensions & $7.25 \mathrm{~mm} \times 160 \mathrm{~mm} \times 227 \mathrm{~mm}$ \\
\hline
\end{tabular}

Table 2 : Experimental plan

\begin{tabular}{cc}
\hline Charge/Discharge Rate & Constant Current \\
\hline 1C & $20 \mathrm{~A}$ \\
$2 \mathrm{C}$ & $40 \mathrm{~A}$ \\
$3 \mathrm{C}$ & $60 \mathrm{~A}$ \\
$4 \mathrm{C}$ & $80 \mathrm{~A}$ \\
\hline
\end{tabular}

Table 3 : Parameters used in the 2D Model [22, 31, 47, 33, 48, 34, 49, 50]

\begin{tabular}{|c|c|c|c|}
\hline Parameter & Notation & Value & Unit \\
\hline Thickness of + ve electrode & $l_{p}$ & 183 & $\mu \mathrm{m}$ \\
\hline Thickness of separator & $l_{s}$ & 52 & $\mu \mathrm{m}$ \\
\hline Thickness of -ve electrode & $l_{n}$ & 100 & $\mu \mathrm{m}$ \\
\hline Particle radius for + ve electrode & $R_{s, p}$ & $1.6 \mathrm{e}-05 / 2$ & $\mu \mathrm{m}$ \\
\hline Particle radius for -ve electrode & $R_{s, n}$ & $2.5 e-05 / 2$ & $\mu \mathrm{m}$ \\
\hline $\begin{array}{l}\text { Maximum solid } \mathrm{Li}^{+} \text {Concentration for } \\
+ \text { ve electrode }\end{array}$ & $C_{s, p, \max }$ & 22806 & $\mathrm{~mol} / \mathrm{m}^{3}$ \\
\hline $\begin{array}{l}\text { Maximum solid } \mathrm{Li}^{+} \text {Concentration for - } \\
\text { ve electrode }\end{array}$ & $C_{s, n, \max }$ & 31370 & $\mathrm{~mol} / \mathrm{m}^{3}$ \\
\hline $\begin{array}{l}\text { Initial solid } \mathrm{Li}^{+} \text {concentration for }+\mathrm{ve} \\
\text { electrode }\end{array}$ & $C_{s, p, 0}$ & 3886.2 & $\mathrm{~mol} / \mathrm{m}^{3}$ \\
\hline $\begin{array}{l}\text { Initial solid } \mathrm{Li}^{+} \text {concentration for -ve } \\
\text { electrode }\end{array}$ & $C_{s, n, 0}$ & 14870.76 & $\mathrm{~mol} / \mathrm{m}^{3}$ \\
\hline $\begin{array}{l}\text { Initial electrolyte } \mathrm{Li}^{+} \text {concentration for } \\
+ \text { ve electrode }\end{array}$ & $C_{o}$ & 2000 & $\mathrm{~mol} / \mathrm{m}^{3}$ \\
\hline $\begin{array}{l}\text { Initial electrolyte } \mathrm{Li}^{+} \text {concentration for - } \\
\text { ve electrode }\end{array}$ & $C_{o}$ & 2000 & $\mathrm{~mol} / \mathrm{m}^{3}$ \\
\hline $\begin{array}{l}\text { Initial electrolyte } \mathrm{Li}^{+} \text {concentration for } \\
\text { separator }\end{array}$ & $C_{o}$ & 2000 & $\mathrm{~mol} / \mathrm{m}^{3}$ \\
\hline Volume fraction for + ve electrode & $\epsilon_{p}$ & 0.444 & - \\
\hline Volume fraction for -ve electrode & $\epsilon_{n}$ & 0.357 & - \\
\hline Volume fraction for separator & $\epsilon_{S}$ & 1 & - \\
\hline
\end{tabular}


Filler fraction for + ve electrode

Filler fraction for -ve electrode

Reference diffusivity for + ve electrode

Reference diffusivity for -ve electrode

Activation energy for + ve electrode

Activation energy for -ve electrode

Conductivity for + ve electrode

Conductivity for -ve electrode

Reference rate constant for $+v e$

electrode

Reference rate constant for -ve electrode

Activation energy for + ve electrode

Activation energy for -ve electrode

Electrolyte diffusivity for + ve electrode

$t_{+}$factor for + ve electrode

Nominal capacity of cell

Minimum stop voltage

Maximum stop voltage

Reference temperature

Universal gas constant

Faraday's constant $\epsilon_{f, p}$

$\epsilon_{f, n}$

$D_{s, p}$

$D_{s, n}$

$E_{d, p}$

$E_{d, n}$

$\sigma_{p}$

$\sigma_{n}$

$k_{p}$

$k_{n}$

$E_{r, p}$

$E_{r, n}$

$D_{e}$

$t_{+}$

$\mathrm{C}$

$V_{\min }$

$V_{\max }$

$T_{\text {ref }}$

$R$

F
0.259

0.172

$1 \mathrm{e}-13$

$3.9 \mathrm{e}-14$

$8.6 \mathrm{e} 4$

$2 \mathrm{e} 4$

3.8

$\mathrm{S} / \mathrm{m}$

100

$\mathrm{S} / \mathrm{m}$

$2.072818 \mathrm{e}-11$

$\mathrm{mol} / \mathrm{m}^{2} \mathrm{~s} /\left(\mathrm{mol} / \mathrm{m}^{3}\right)^{1.5}$

2.072818e-11

$\mathrm{mol} / \mathrm{m}^{2} \mathrm{~s} /\left(\mathrm{mol} / \mathrm{m}^{3}\right)^{1.5}$

$9 \mathrm{e} 3$

$2 \mathrm{e} 4$

7.5e-11

0.363

20

2.0

4.1

298

8.3143

96485 $\mathrm{m}^{2} / \mathrm{s}$

-

$\mathrm{Ah}$

V

V

K

$\mathrm{kJ} / \mathrm{kg}$ mole $\mathrm{K}$

Columb/mole

Table 4 : Material Properties used in the simulation [22, 31, 49]

\begin{tabular}{lccc}
\hline \multicolumn{1}{c}{ Property } & Symbol & Value & Unit \\
\hline Density for positive tab & $\rho_{p}$ & 2719 & $\mathrm{~kg} / \mathrm{m}^{3}$ \\
Density for negative tab & $\rho_{n}$ & 8978 & $\mathrm{~kg} / \mathrm{m}^{3}$ \\
Density for active zone & $\rho_{a}$ & 2092 & $\mathrm{~kg} / \mathrm{m}^{3}$ \\
Specific heat for positive tab & $C_{p, p}$ & 871 & $\mathrm{~J} / \mathrm{kg}-\mathrm{K}$ \\
Specific heat for negative tab & $C_{p, n}$ & 381 & $\mathrm{~J} / \mathrm{kg}-\mathrm{K}$ \\
Specific heat for active zone & $C_{p, a}$ & 678 & $\mathrm{~J} / \mathrm{kg}-\mathrm{K}$ \\
Thermal conductivity for positive tab & $K_{p}$ & 202 & $\mathrm{~W} / \mathrm{m}-\mathrm{K}$ \\
Thermal conductivity for negative tab & $K_{n}$ & 387.6 & $\mathrm{~W} / \mathrm{m}-\mathrm{K}$ \\
Thermal conductivity for active zone & $K_{a}$ & 18.2 & $\mathrm{~W} / \mathrm{m}-\mathrm{K}$ \\
\hline
\end{tabular}




\section{Figures}

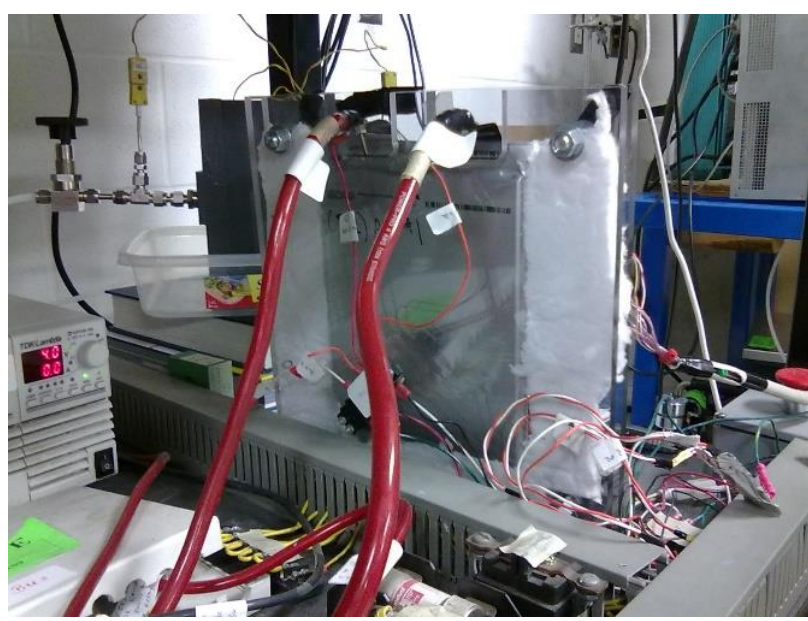

a) Battery testing

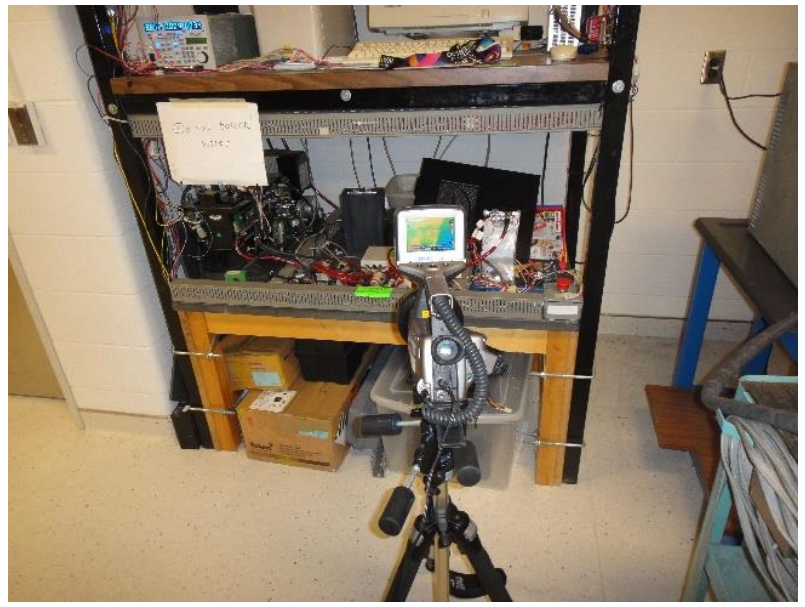

b) IR imaging

Figure 1 : Experimental set-up during a) battery testing and b) IR imaging

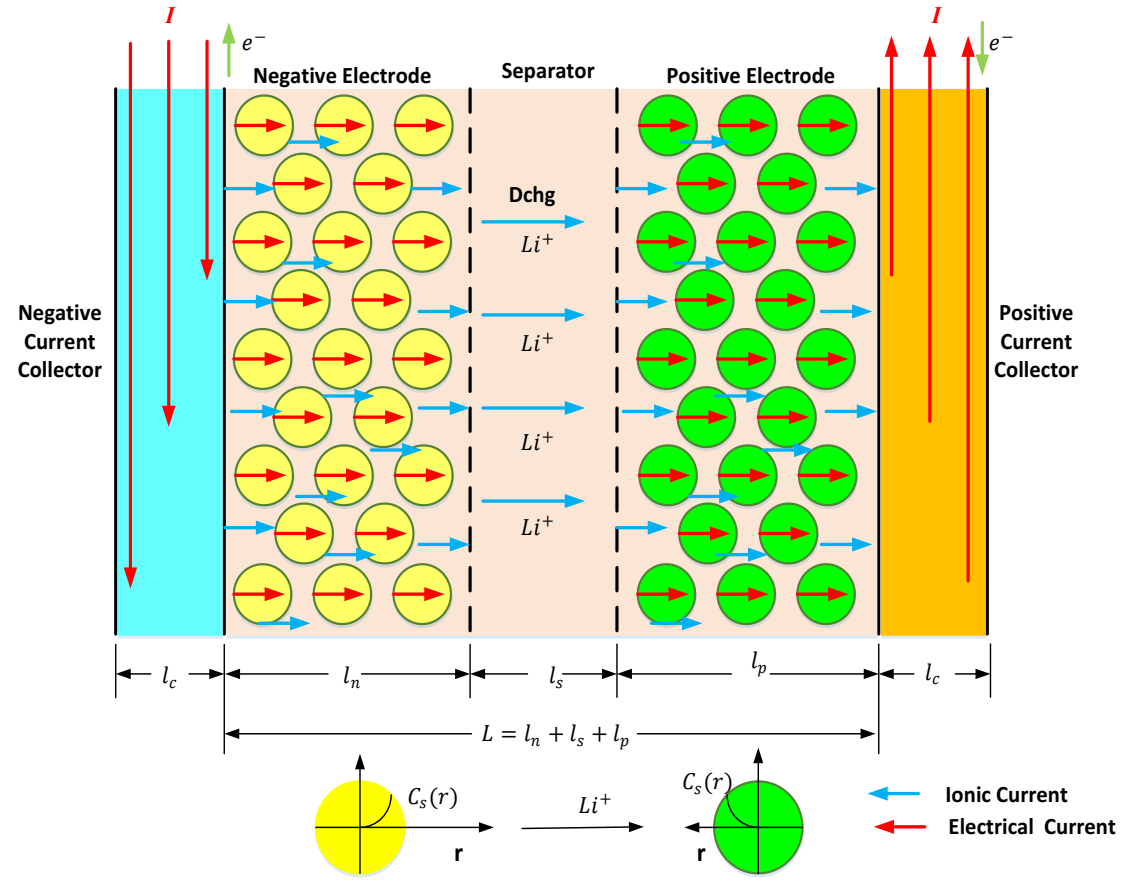

Figure 2 : Schematic diagram of lithium-ion battery cell configuration for the pseudo-two dimensional multi-particle model (modified from [33]) 


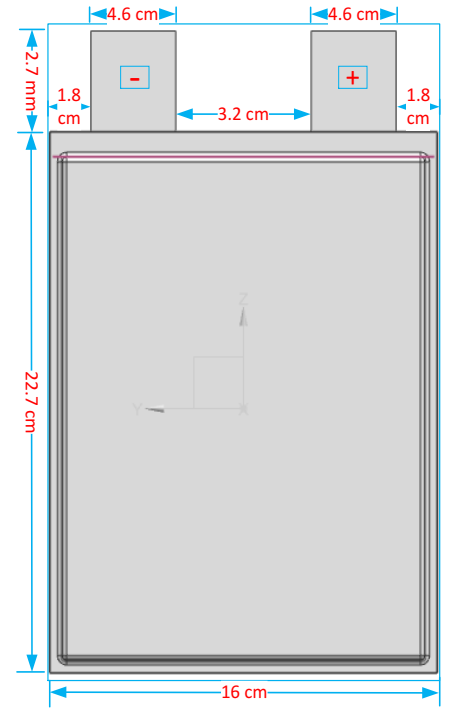

a) Battery cell geometry

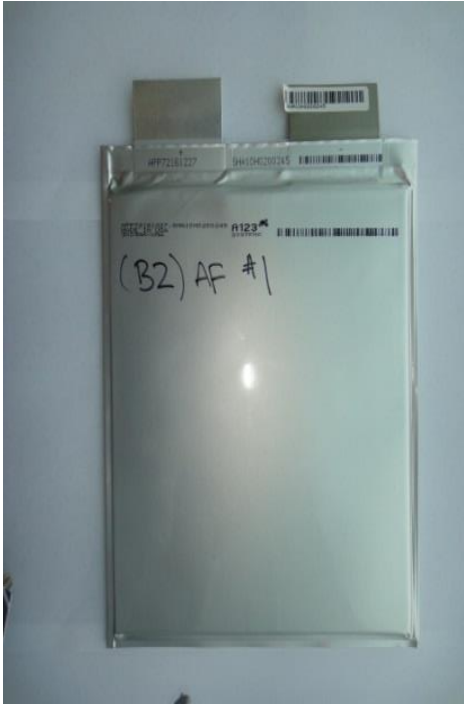

b) Picture of battery cell

Figure 3 : Lithium-ion prismatic cell geometry for ECT model

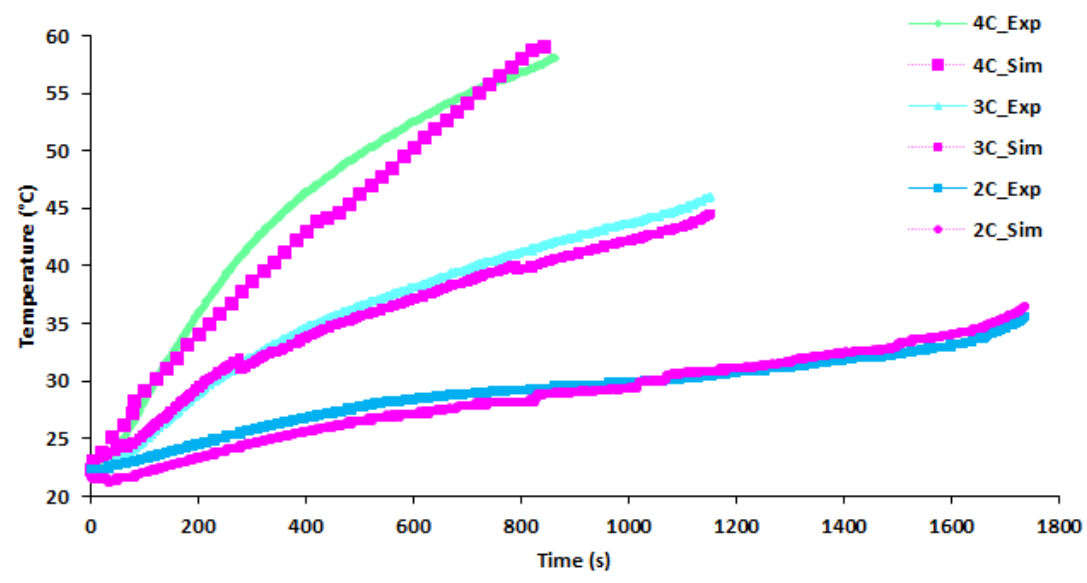

Figure 4 : Validation of experimental and simulated results at $2 \mathrm{C}, 3 \mathrm{C}$, and $4 \mathrm{C}$ discharge rate 


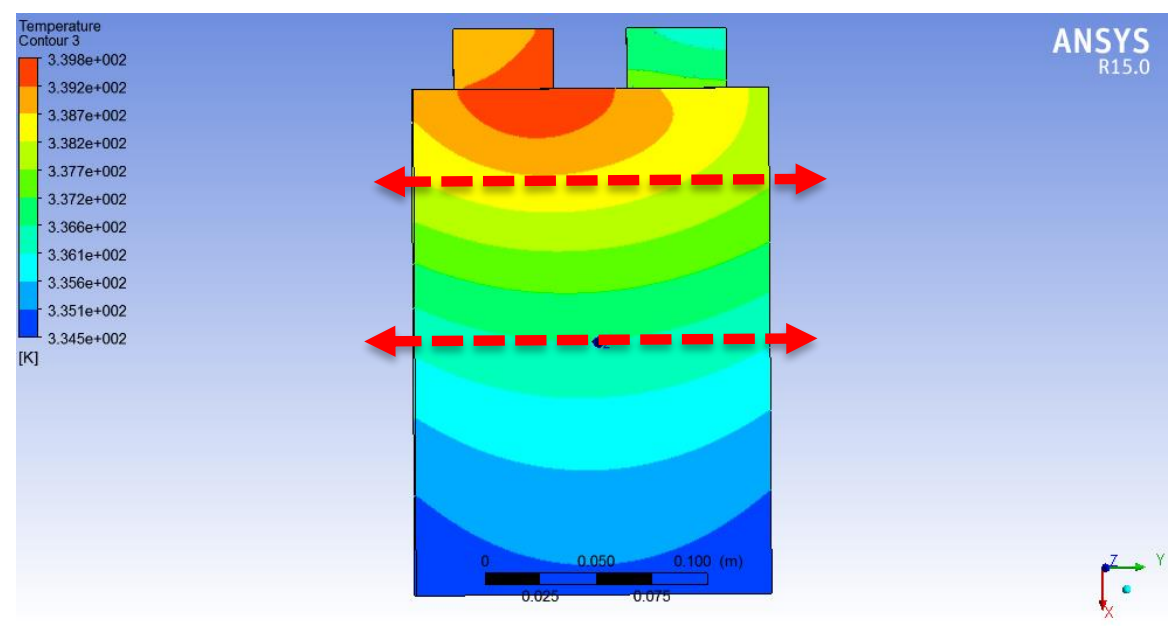

(a) Simulated result at $4 \mathrm{C}$ discharge rate

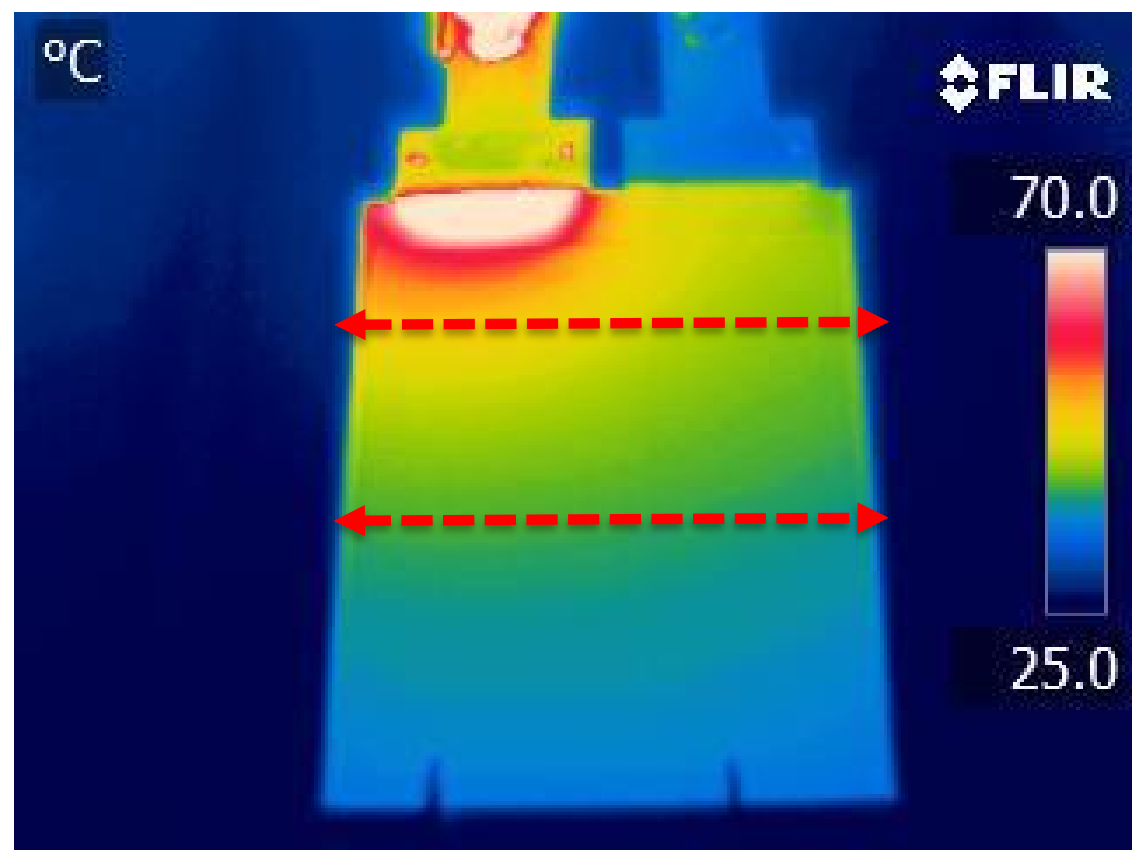

(b) IR imaging result at $4 \mathrm{C}$ discharge rate

Figure 5 : Comparison of temperature contour of battery at $4 \mathrm{C}$ discharge rate (simulated and real image) 


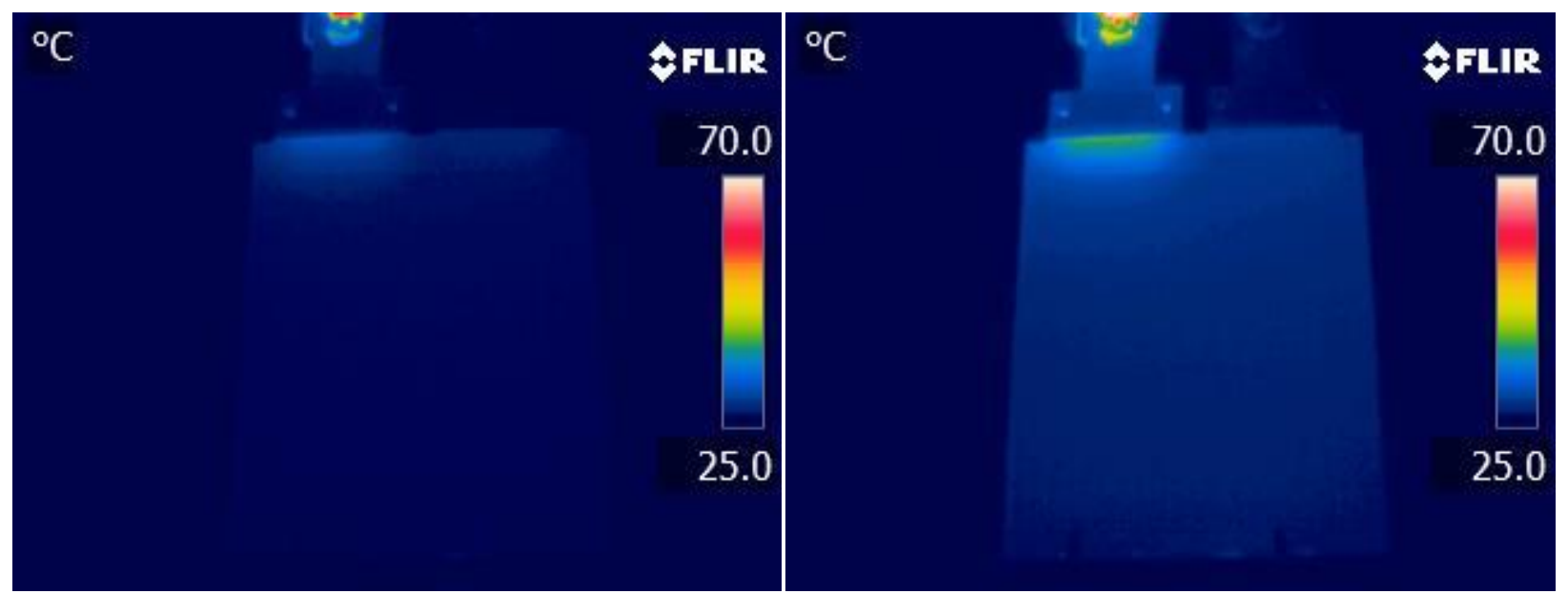

After 30 s

After 120 s

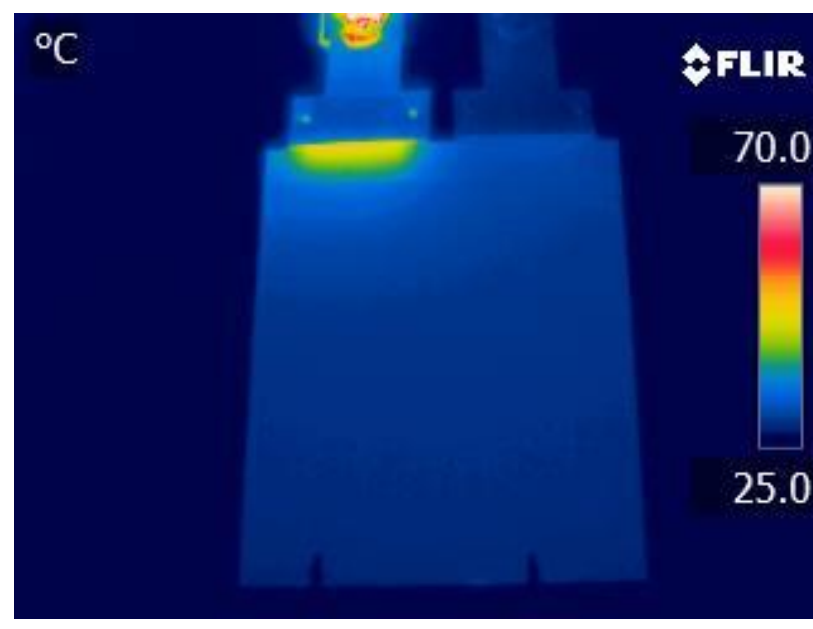

After 180 s

After 300 s
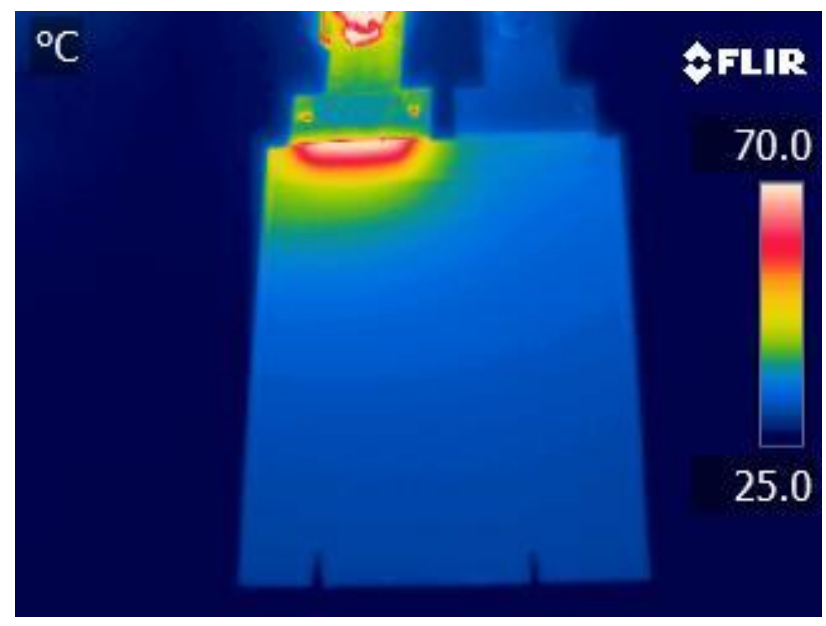

After 360 s

After 480 s 


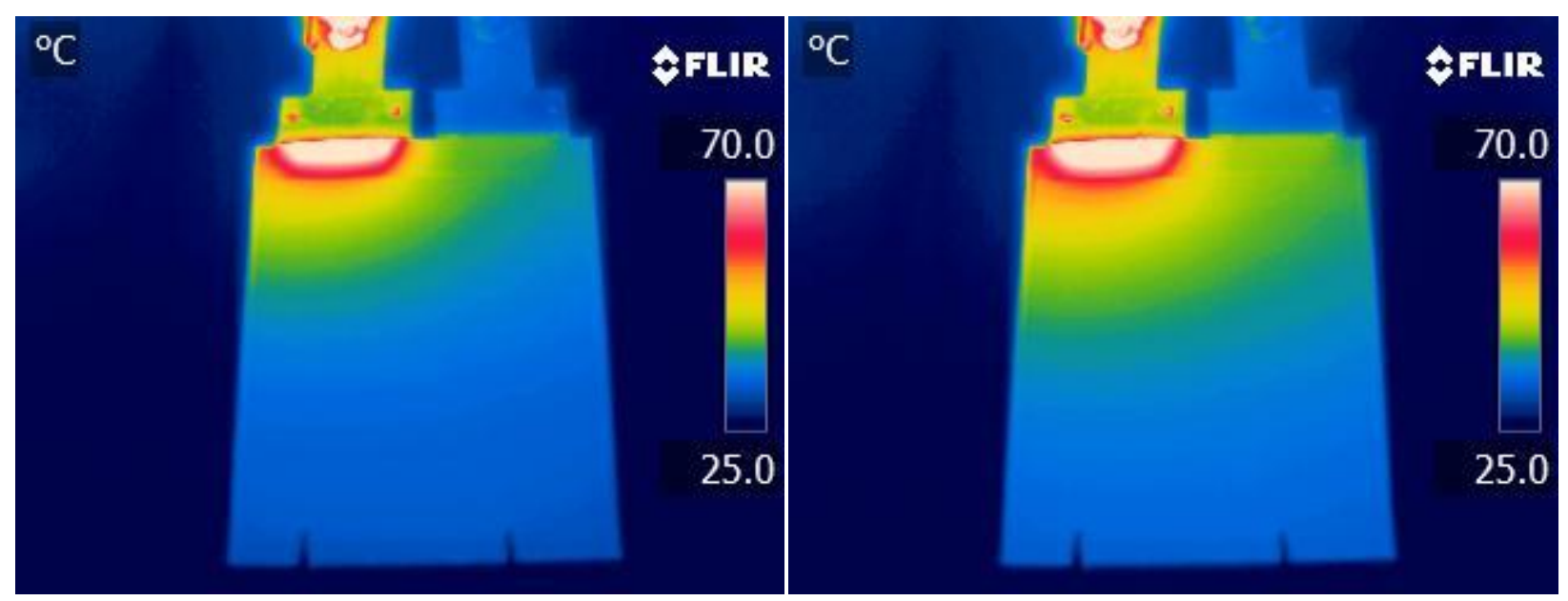

After 540 s

After 660 s
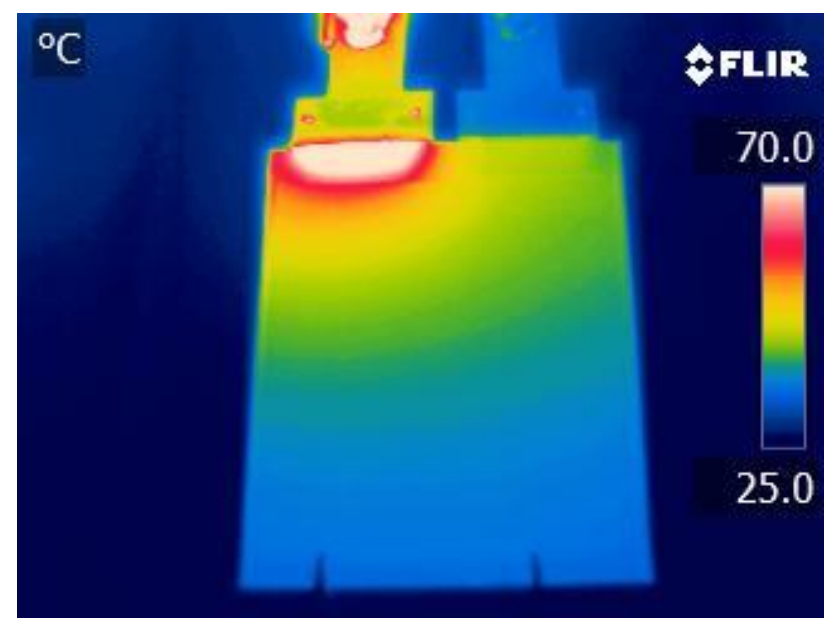

After $720 \mathrm{~s}$

After 840 s
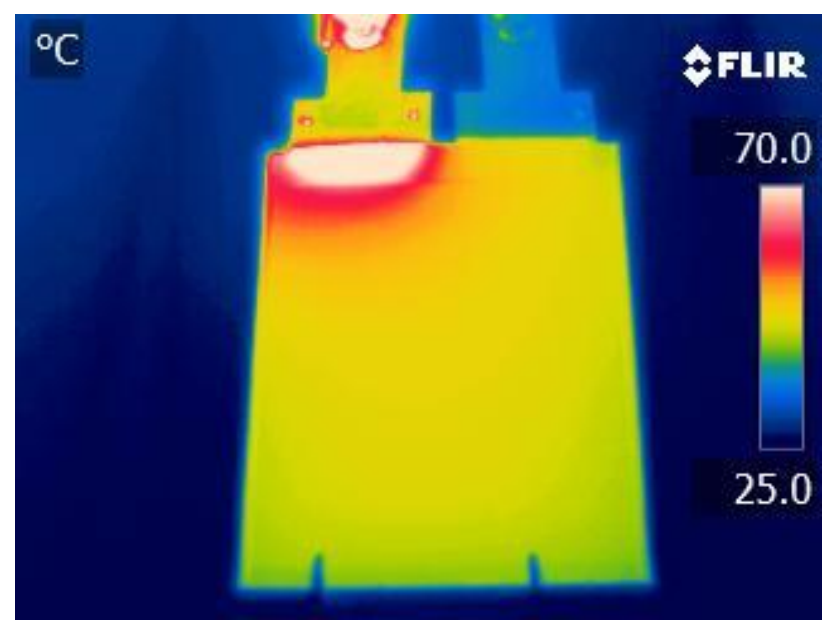

After 900 s
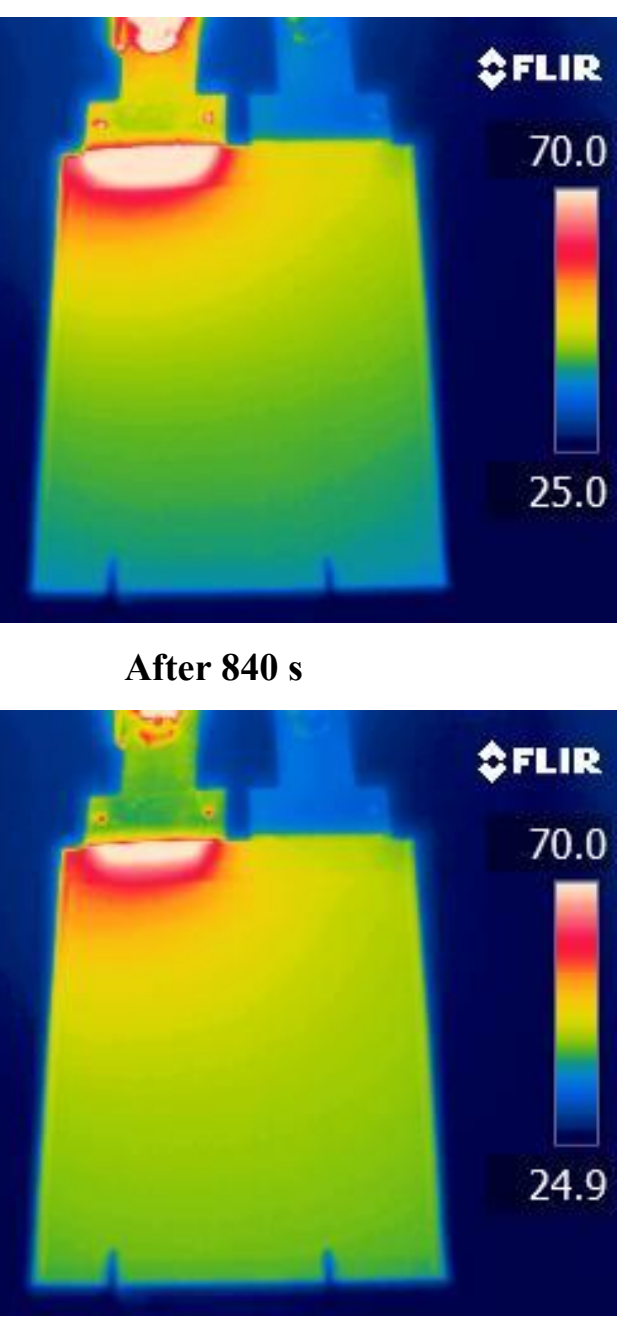

After 1020 s 


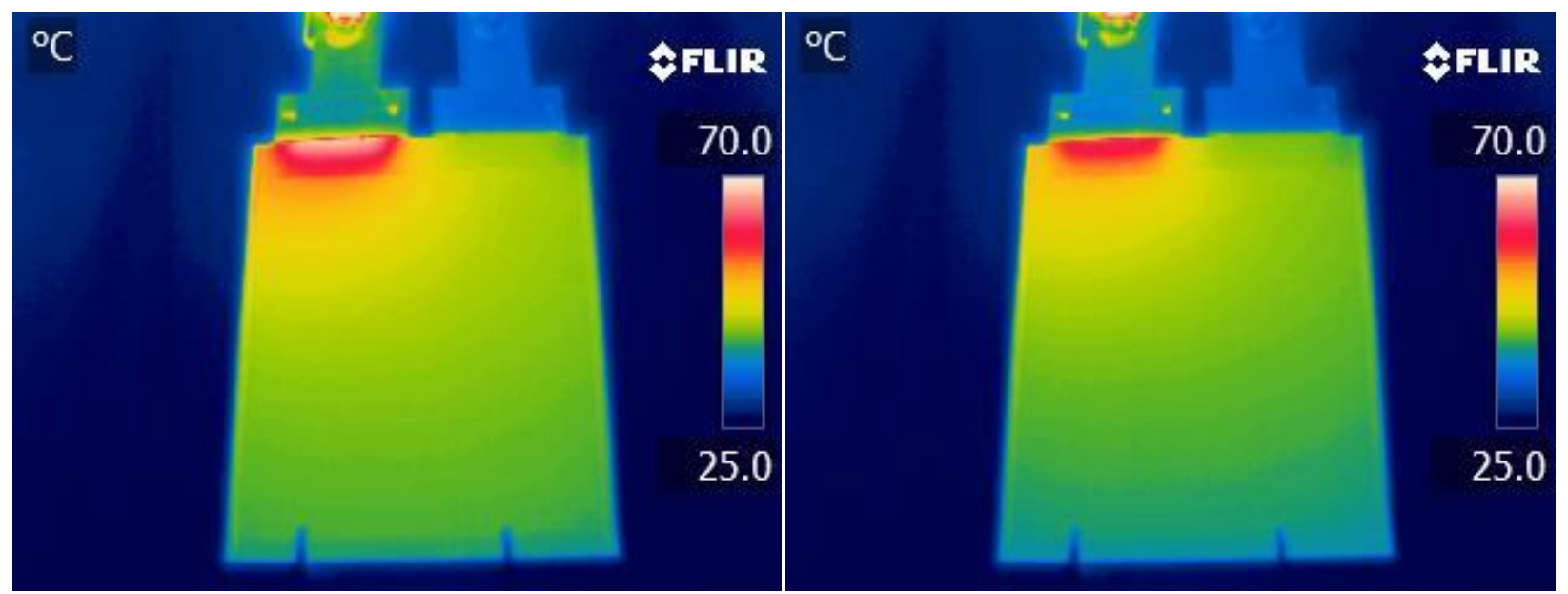

After 1080 s

After 1140 s
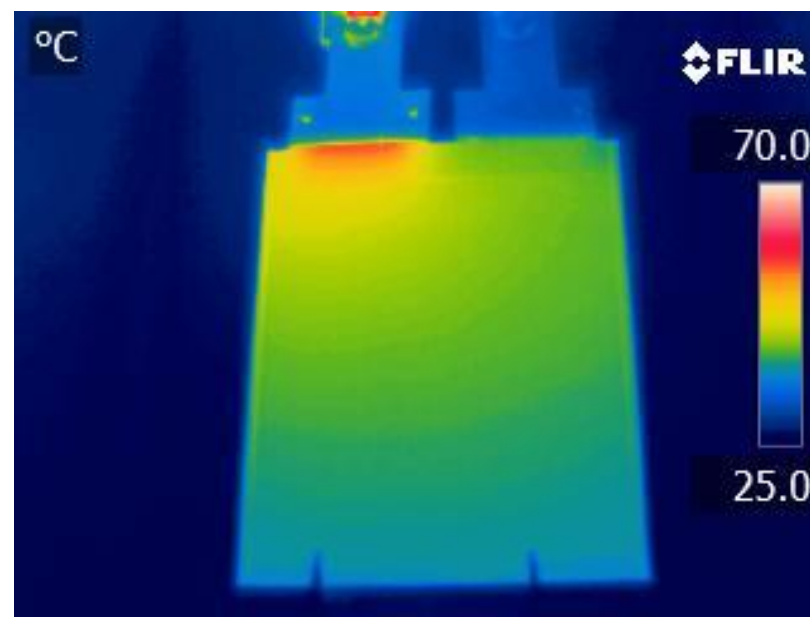

fFlIR

After $1200 \mathrm{~s}$

After $1260 \mathrm{~s}$
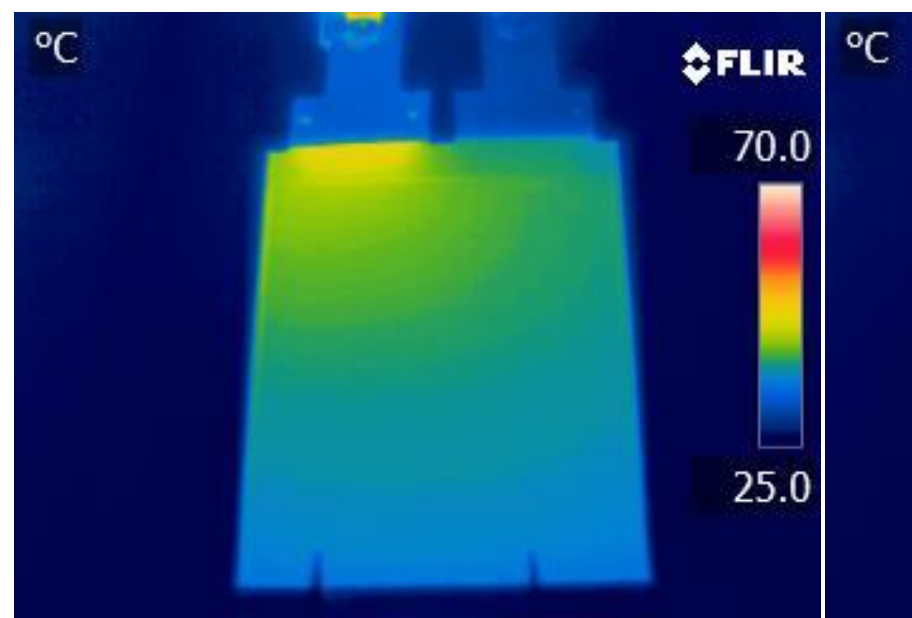

After 1320 s

After 1380 s 


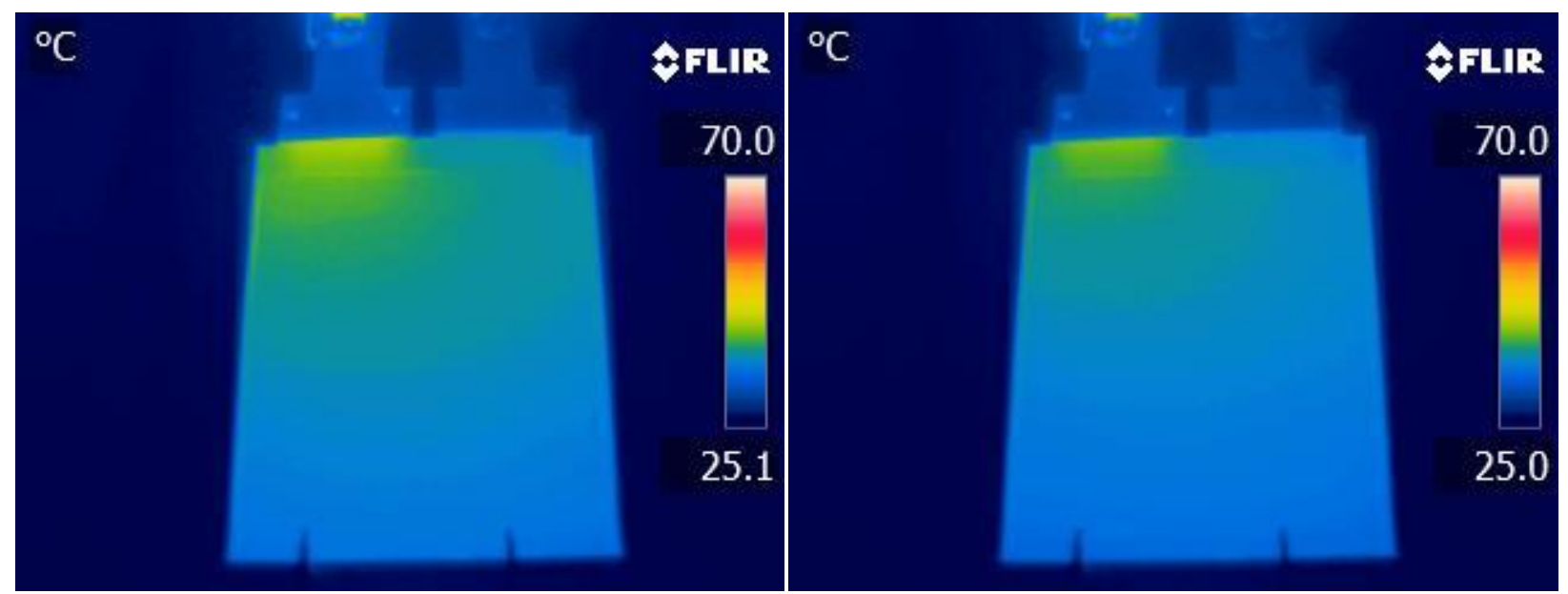

After 1440 s

After 1500 s
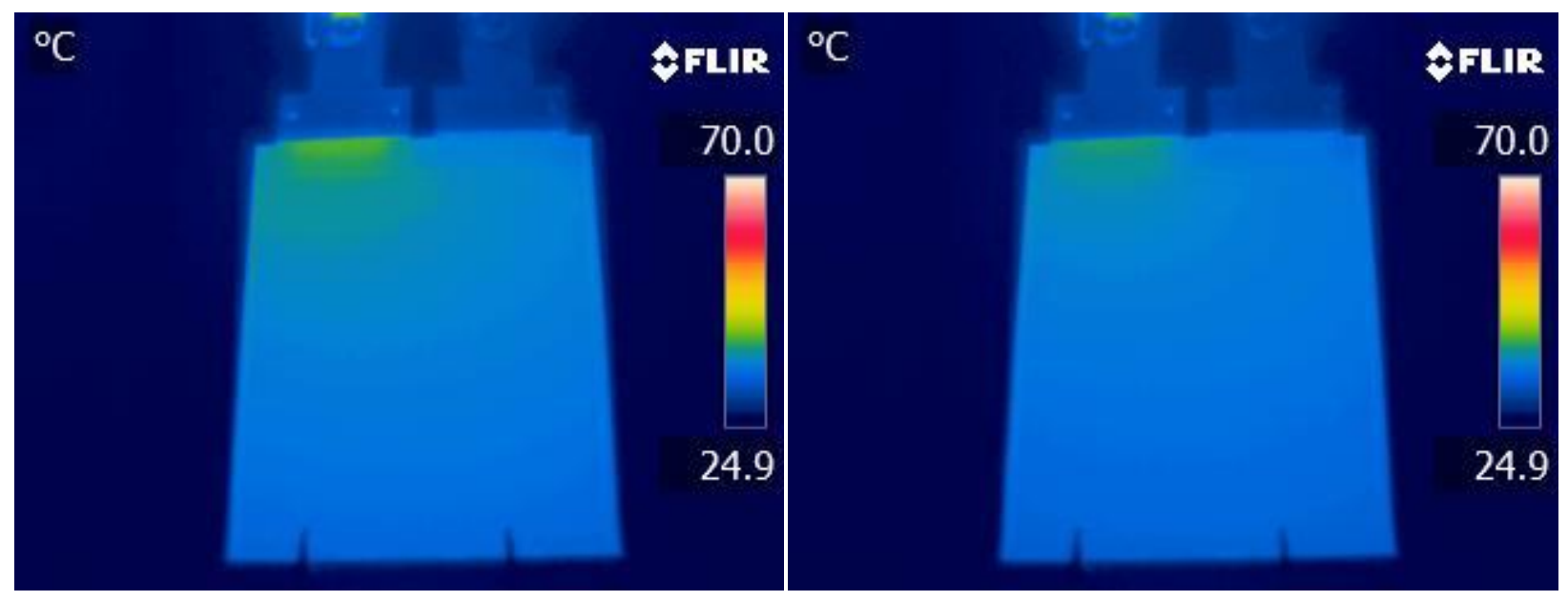

After 1560 s

After 1620 s
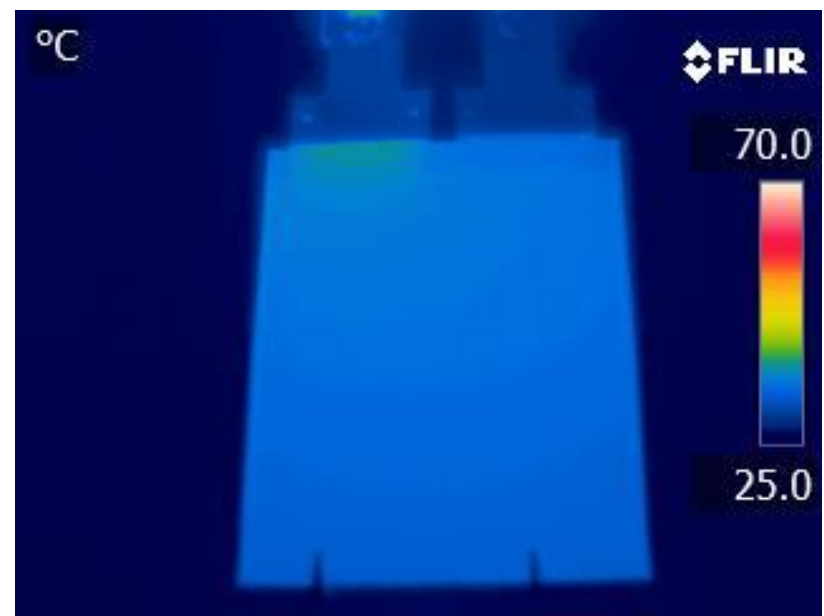

After 1680 s

After 1740 s

Figure 6 : Series of IR images during 4C discharge 